\title{
المجلد: (الأول).
}

العدد: الثالث (يوليو 2019).

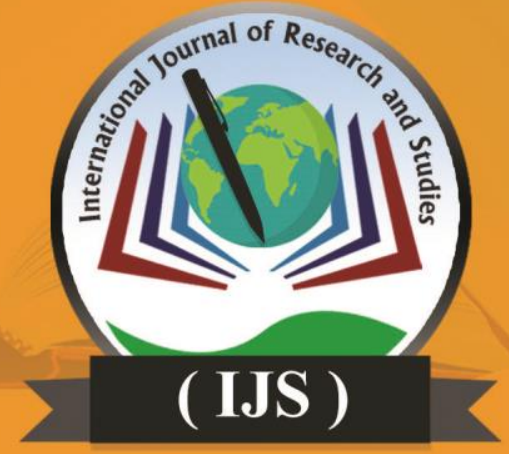

International Jomrial of Research and Studies

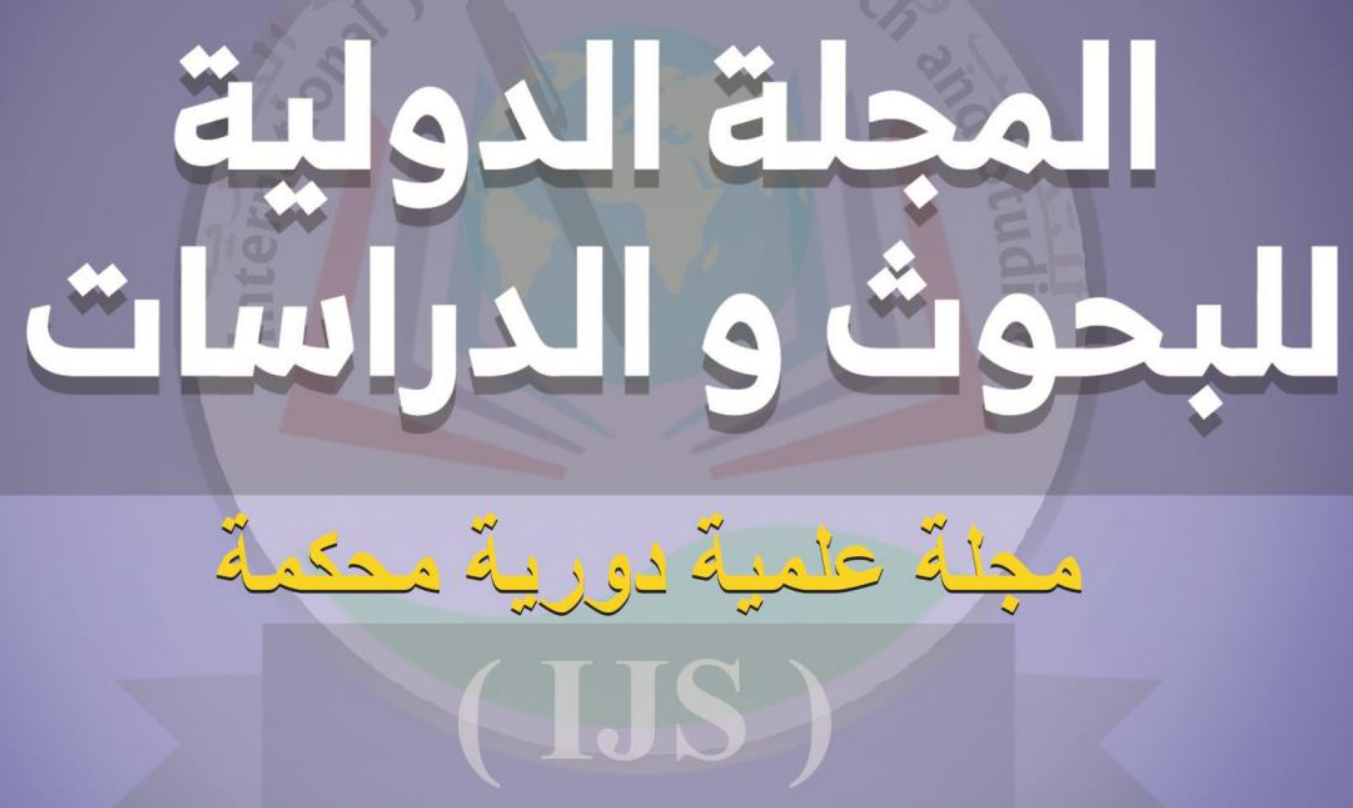

تصدروا آكاديمية

رواد التميز للتدريب

والإستشارات والتنمية البشرية رلتبية 


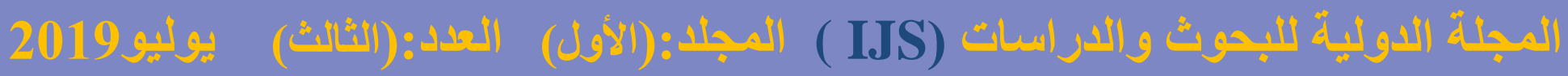
د. رانيا الصاوي عبده عبد القوي، (فاعلية برنامج إرشادي مقترح لخفض الوسواس القهي لاى طالبات الجامعة).

فاعلية برنامج إرشادي مقترح لخفض الوسواس القهري لاى طالبات

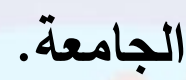

\section{إعداد: الدكتورة/ رانيا الصاوي عبده عبد القوي.}

أستاذ الصحة النفسية، كلية العلوم والآداب بالبدائع، جامعة القصيم، المملكة العربية السعودية.

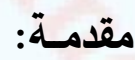

يثكل الثباب شريحة عمريـة مهمة ومحددة بيولوجياً ونفسياً واجتماعياً، تختلف في

طبيعتها عن مراحل الثخصية السابقة واللاحقة لها، هذا الاختلاف لا يعني فصل المرحلة عن

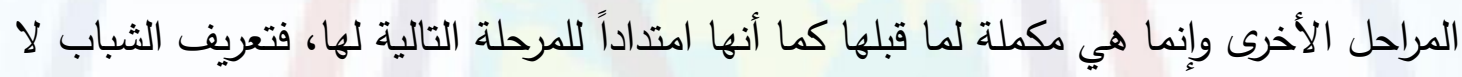
ينبغي أن يقتصر على التعريف التقليدي والذي ينحصر في أنه فترة عمريـة معينـة تتحدد في إطارها بعض المظاهر النمائية، واستبدالها بنظرة أكثر تقدمية تأخذ بعين الاعتبار متغيرات أخرى خلاف المتغير العمري، فالثباب طاقة دينامية مؤثرة إلى أقصى حد يمكن استثمارها في التعامل مع المشكلات المتمعية من خلال تفاعله الإيجابي مع أنساق المجتمع المختلفة.

يعد شباب الجامعة أحد أهم الثرائح المجتمعية، نظرا للآمال المعقودة عليهم في حمل لواء تتميـة المجتمع مستقبلا وهو الأمـر الذي يتطلب ضـرورة الاهتمـام بهم على كافة المستويات

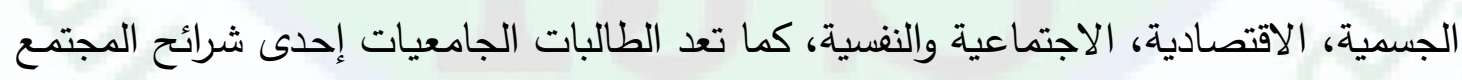
الموكل لهن تتمية المجتمعات، هذا الهدف لا يتحقق إلا بوجود طالبات جامعيات يتمتعن بعلاقة صحية مع ذواتهن لتحققن مستوى عال من التوافق النفسي والاجتماعي.

قد يتعرض بعض الثـباب لمواقف أسرية وبيئية ضـاغطة فيكون عرضـهـ للعديد مـن

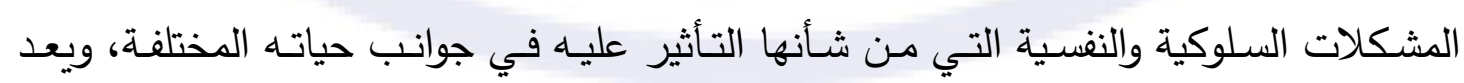
اضطراب الوسواس القهري واحدا من الاضطرابات الثائعة في جميع المجتمعات، وهو يؤثر على مجمل حياة الفرد وتوافقه النفسي والاجتماعي، وقد لوحظ أن بعض المصابين بالوسواس القهري 


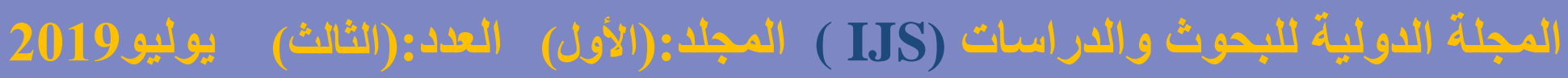

د. رانيا الصاوي عبده عبد القوي، (فاعلية برنامج إرشادي مقترح لخفض الوسواس القهري لاى طالبات الجامعة).

يعانون معاناة نفسية شديدة، ويحاولون التوافق كثيراً للتغلب على معاناتهم، كما أن طول المعاناة من هذا الاضطراب - الذي قد يمتد إلى سنوات- وشدة الألم والكدر والضيق الذي يحدث بسبب ذلك، كذلك وطأة المرض نفسه، يدفع الشباب إلى طلب العلاج النفسي بهدف تخفيف معاناتهم وآلامهم، خاصة أن ذلك الأثر يمتد ليثمل معظم جوانب حياة الفرد، مما يزيد من المخاطر حول مواجهة الحياة المستقبلية.

يعد الوسواس القهري أحد الأمراض النفسية العصابية التي يعلم فيها المريض علم اليقين بعدم صحة أفكاره، ويأتي المرض عادة في هيئة أفكار أو اندفاعات أو مخاوف، كما قد يكون في هيئة طقوس حركيـة مستمرة أو دوريـة مـع يقين المـريض بتفاهـة هذه الوسـاوس ولا معقوليتها، وعلمه الأكيد أنها لا تستحق منه هذا الاهتمام، يحاول المريض باستمرار مقاومة هذه الوساوس وعدم الاستسلام لها.

مـن هنـا جـاء اهتمـت هذه الدراسـة بالطالبـات الجامعيـات اللاتي يعـانين مـن اضـطراب الوسواس القهري وذلك من خـلال استخدام برنـامج إرشـادي جمعي يعتمد على فنيات العـلاج المعرفي السلوكي باعتباره واحدا من الخيارات الناجحة في خفض اضطراب الوسواس القهري. أولا: أهمية الدراسة: تبرز أهمية الدراسة على النحو التالي: 1. مسـاهمة الدراسـة الراهنـة في اكتساب الطالبات الجامعيات بعض المهارات التي تسـاعدهن على خفض اضطراب الوسواس القهري مما ينعكس على توافقهن النفسي والاجتماعي وما لذلك من مردود ايجابي بوجه عام.

2. أهمية المرحلة العمرية لعينة الدراسـة (مرحلة الثباب الجامعي) وما لها من أهمية في حياة الطالبات الجامعيات المستقبلية.

3. إلقاء الضوء بشكل علمي على أحد أشكال التدخلات العلاجية من حيث إعداد برنامج قائم على إرشاد جمعي معرفي سلوكي لخفض اضطراب الوسواس القهري.

4. إن إعداد مثل هذا البرنامج سيساعد في فتح مجالات بحثية وتطبيقات جديدة في المجالات التربوية والعيادية والإرشادية. 


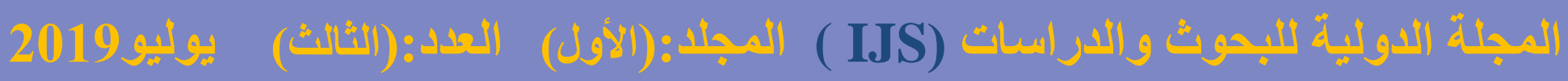

د. رانيا الصاوي عبده عبد القوي، (فاعلية برنامج إرشادي مقترح لخفض الوسواس القهري لاى طالبات الجامعة).

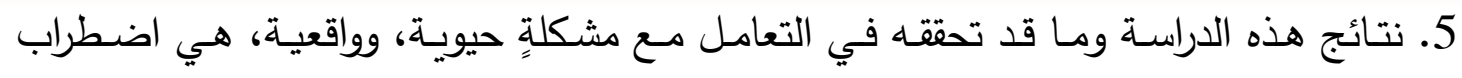
العصاب القهري، لاى الطالبات الجامعيات وفاعليه البرنامج في خفض حده اضطراب الوسواس

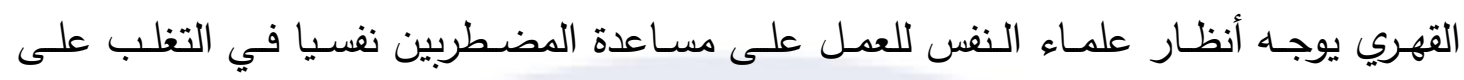
مشكلاتهم وتصميم ما يناسبهم من برامج مختلفة.

6. أشـارت الدراسـات السابقة إلى انتشار اضطراب الوسـاوس القهريـة إذ قدرت نسبة الانتشـار للوسواس القهري (0.05\%) بين عامة الناس، ولكن يعتقد أنه أكثر شيوعاً من هذه النسبة، وأن طبيعة التكتم للى هؤلاء المرضى هي سبب نقص معدل الانتشار وهم يمثلون(1\%) من مرضى لهى

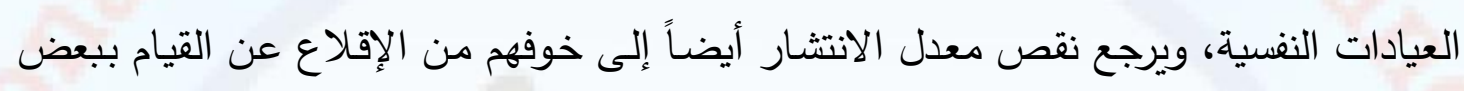
الطقوس التي من شأنها أن تخفض من حده الكدر والتوتر اللذين يعانون منهما نتيجة لأفكارهم الوسواسية، أو الطقوس التي تمنع حدوث كارثة أو كرب معين يتوقعون حدوثه إن لم يقوموا بها ولهذا يفضلون الابتعاد عن العيادات النفسية والبقاء على ما هم عليه. (البشر، وفرج، 2002:

.$(208$

ثانياً: مشكلة الدراسة وتساؤلاتها:

تتحدد مشكلة الدراسة في دراسة فاعلية تأثير برنامج إرشادي قائم على استخدام فنيات

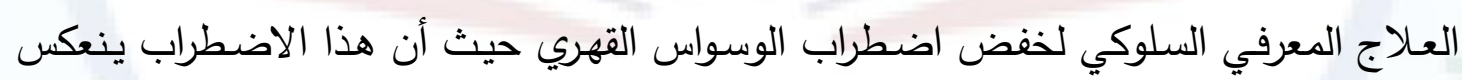

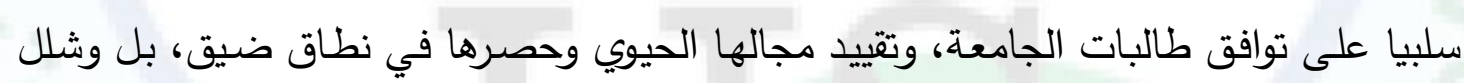
إرادتها أحياناً بشكل تام مما يعوق تكيفها مع من حولها، حيث أن مرحلة التعليم الجامعي تثكل

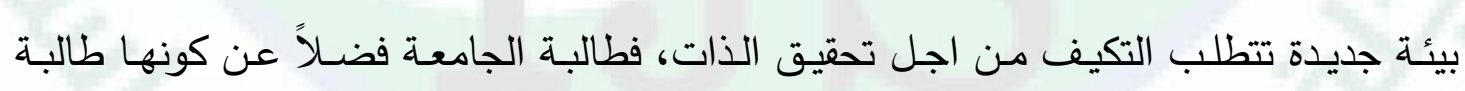

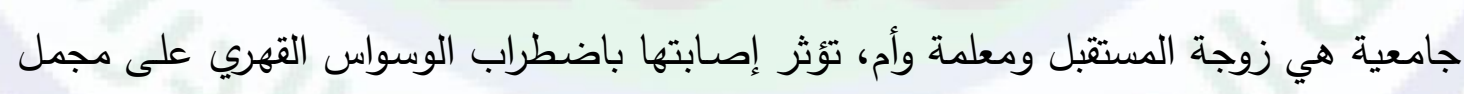
حياتها الثخصية، الاجتماعية، الدراسية كما يؤثر على أسرتها بشكل عام، مما يفقدها توازنها النفسي.

لقد أشار عكاشة (2003) بأن هذا العصاب من أكثر الاضطرابات ألماً ومعاناة وقد توصلت نتائج دراسته أن نسبة المترددين على العيادة النفسية بمستشفى عين شمس حوالي لئي 


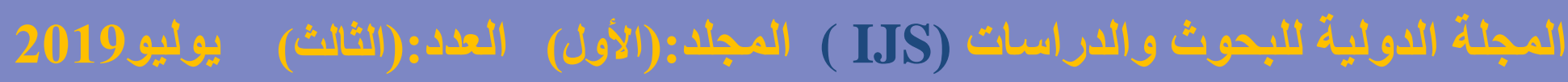

د. رانيا الصاوي عبده عبد القوي، (فاعلية برنامج إرشادي مقترح لذفض الوسواس القهري لاى طالبات الجامعة).

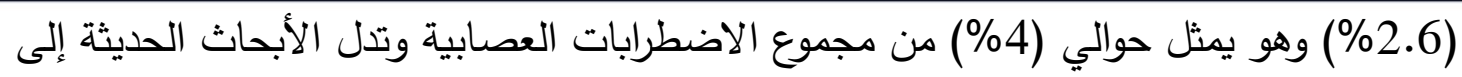

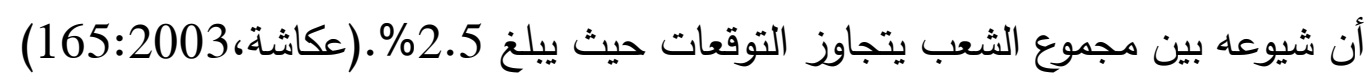

كمـا توصـلت هولانـ (2006) إلى أن اضـطراب الوسـواس القهري يعد المـرض الرابع

الأكثر تشخيصاً في العالم بشكل عام، وفى الولايات المتحدة بشكل خاص، إن راشداً من بين

أربعين من الراشدين تنطبق عليه محكات اضطراب الوسواس القهري التشخيصية في مرحلة من

مراحل حياته. (هولاند،2006: 213)، وأشارت إحدى الدراسات أن نسبة (50\%) من المرضى

بدأت أعراضهم قبل الرابعة والعشرين من العمر • (توفيق: 2000).

مما سبق يمكن صياغة مشكلة الدراسة في التساؤلات الآتية:

1. هل هناك فروق دالـة إحصـائيا في الدرجـة الكلية لمقياس يل براون للوسواس القهري بين

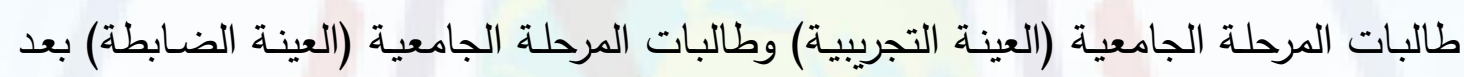
تطبيق البرنامج القائم على الإشاد الجمعي المعرفي السلوكي؟

2. هل هناك فروق دالة إحصائيا في الدرجة الكلية لقائمة المودزلي للوسواس القهري بين طالبات المرحلة الجامعية (العينـة التجريبية) وطالبات المرحلة الجامعية (العينـة الضـابطة) بعد تطبيق البرنامج القائم على الإرشاد الجمعي المعرفي السلوكي؟

3. هل هناك فروق دالة إحصـائيا في الدرجة الكلية لمقياس يلـ براون للوسواس القهري بين طالبـات المرحلـة الجامعيـة (العينـة التجريبيـة) قبل وبعد تطبيق البرنـامج القـائم على الإرشـاد

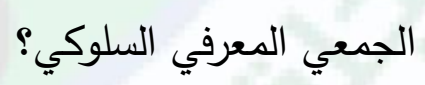

4. هل هناك فروق دالة إحصائيا في الدرجة الكلية لقائمة المودزلي للوسواس القهري بين طالبات المرحلـة الجامعيـة (العينة التجريبية) قبل وبعد تطبيق البرنـامج القـائم على الإرشـاد الجمعي لهي

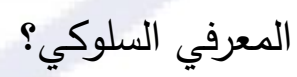

5. هل هناك فروق دالة إحصائيا بين طالبات المرحلة الجامعية في الدرجة الكلية لمقياس يل براون للوسواس القهري في القياسين (البعدي والتتبعي)؟ 


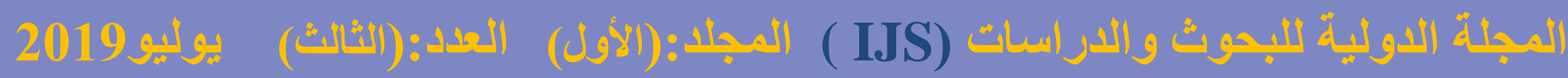
د. درانيا الصاوي عبده عبد القوي، (فاعلية برنامج إرشادي مقترح لخفض الوسواس القهري لاى طالبات الجامعة).

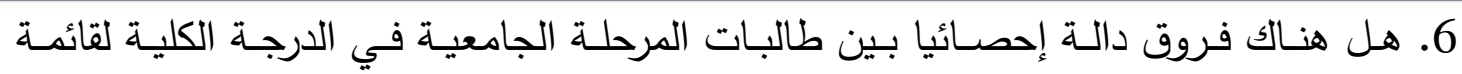
المودزلي للوسواس القهري في القياسين (البعدي والتتبعي)؟ ثالثاً: أهداف الدراسة: - م

سعت الدراسة إلى اختبار مدى فعالية برنامج إرشاد جمعي يعتمد على فنيات العلاج

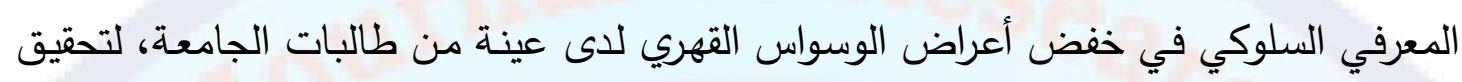
مزيد من الصحة النفسية لهن، في ضوء هذا الهذف العام سعت الباحثة إلى:

1. إكساب طالبات المرحلة الجامعية بعض المهارات المعرفية والسلوكية التي تساعدهن على مواجهة اضطراب الوسواس القهري ومواجهة مشكلات الحياة وضغوطها باستخدام هذه المهارات. 2. مدى استمرار فاعلية البرنامج العلاجي - إن وجدت لله فاعلية - إلى ما بعد فترة المتابعة.

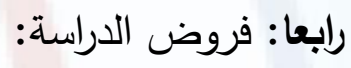

يتحدد الفرض الرئيس لهذه الدراسة التحقق من مدى فاعلية برنامج إرشادي مقترح لخفض

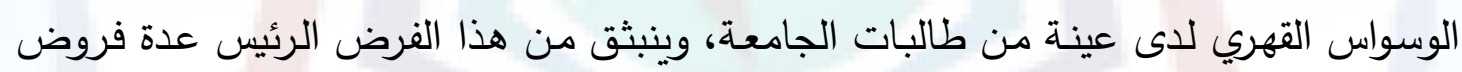

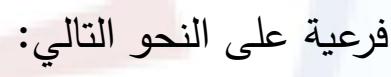

1. توجد فروق دالة إحصائيا في الدرجة الكلية لمقياس يل براون للوسواس القهري بين طالبات

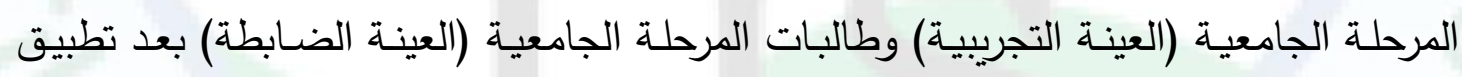
البرنامج القائم على الإرشاد الجمعي المعرفي السلوكي لصالح المجموعة التجريبية. 2. توجد فروق دالة إحصـائيا في الدرجة الكلية لقائمة المودزلي للوسواس القهري بين طالبات المرحلة الجامعية (العينة التجريبية) وطالبات المرحلة الجامعية (العينـة الضـابطة) بعد تطبيق البرنامج القائم على الإرشاد الجمعي المعرفي السلوكي لصالح المجموعة التجريبية. 3. توجد فروق دالة إحصائيا في الدرجة الكلية لمقياس يل براون للوسواس القهري بين طالبات

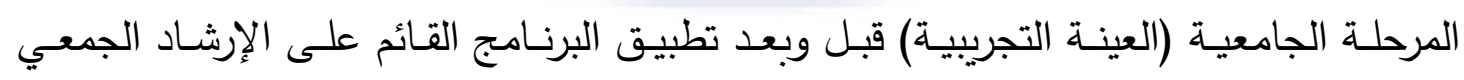
المعرفي السلوكي لصالح القياس البعدي.

International Journal of Research and Studies (ijs) It is issued by the Excellence Pioneers Academy 


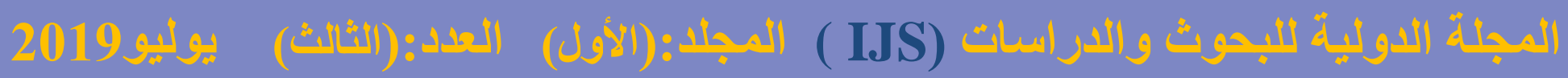

د. رانيا الصاوي عبده عبد القوي، (فاعلية برنامج إرشادي مقترح لخفض الوسواس القهري لاى طالبات الجامعة).

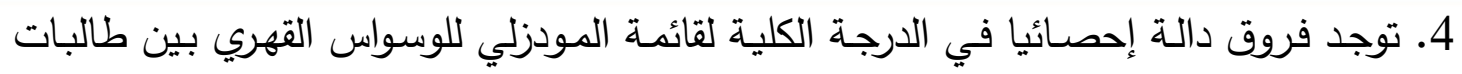
المرحلـة الجامعيـة (العينـة التجريبيـة) قبل وبعد تطبيق البرنـامج القـائم على الإرشـاد الجمعي لركي المعرفي السلوكي لصالح القياس البعدي.

5. توجد فروق دالة إحصائيا بين طالبات المرحلة الجامعية في الدرجة الكلية لمقياس يل براون للوسواس القهري في القياسين (البعدي والتتبعي) لصالح القياس التتبعي. 6. توجد فروق دالة إحصائيا بين طالبات المرحلة الجامعية في الدرجة الكلية لقائمة المودزلي للوسواس القهري في القياسين (البعدي والتتبعي) لصالح القياس التتبعي.

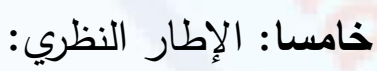

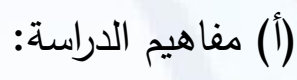

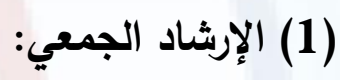

بعد مراجعـة الباحثة العديـد مـن التعريفـات التي قدمت في مفهوم الإرشـاد الجمعي (سمير

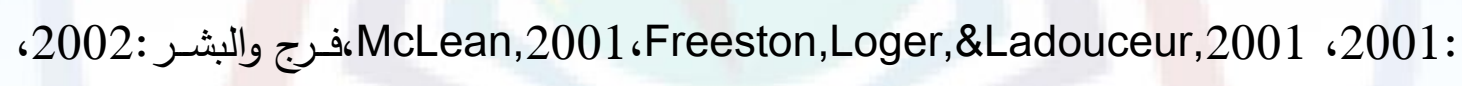
Sookman, ،Anderson,\&Rees,2007،Wilson,\&Chambless,2005، 2004، 2004 \&Steketee

تتبنى الباحثة في الدراسة الراهنة مفهوم الإرشاد الجمعي باعتباره احد الأساليب الإرشادية

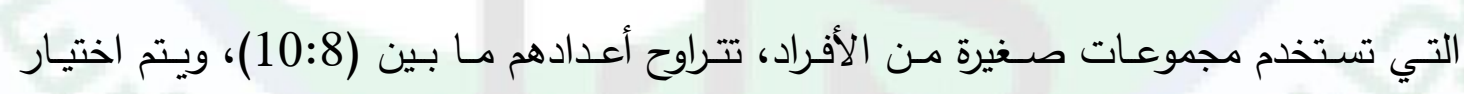
الطالبات الجامعيات بطريقة مقصودة حيث يثتركن في المعاناة من صعوبات متشابها وفي تقارب أعمارهن، وتتلقى الطالبات خلال الجلسات مجموعة من المهارات الإرشادية تحت مظلة مفاهيم العلاج المعرفي السلوكي للتغلب على هذه الصعوبات. (2) البرنامج قائم على فنيات العلاج المعرفي السلوكي: 


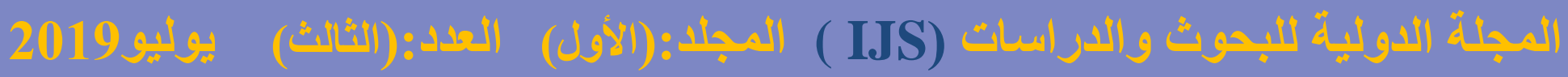

د. رانيا الصاوي عبده عبد القوي، (فاعلية برنامج إرشادي مقترح لخفض الوسواس القهري لاى طالبات الجامعة).

تتعامل الدراسة الراهنة مع السلوك اللاتكيفي باعتباره نتاجا للتنكير غير الوظيفي، من هنا

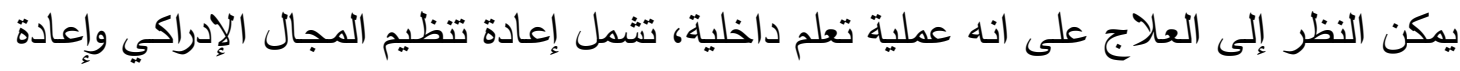
تنظيم الأفكار المرتبطة بالعلاقات بين الأحداث والمؤثرات البيئية المختلفة الكاله

.(Green, 2005 Bradburg, 2005; Rufer, et., 2006 \&Guggisberg, 2005)

تم وصف المراحل العلاجية كما تثير (الثطرات،

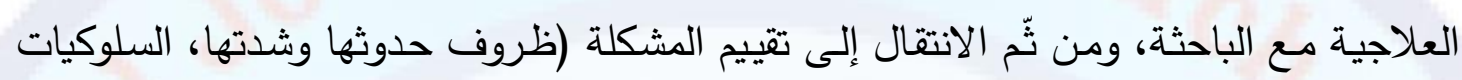

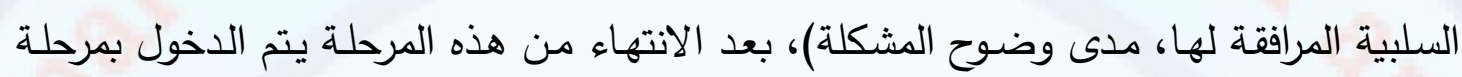

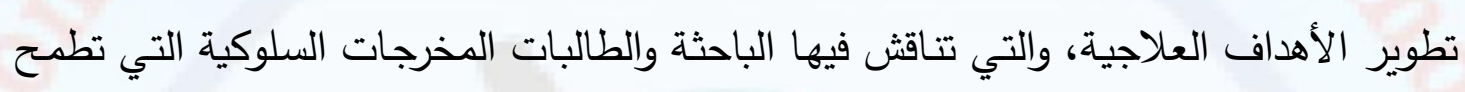

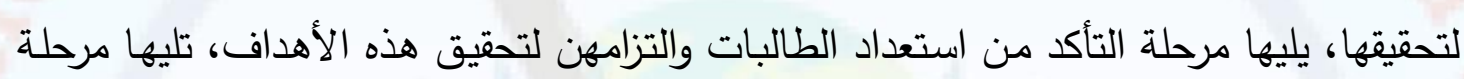

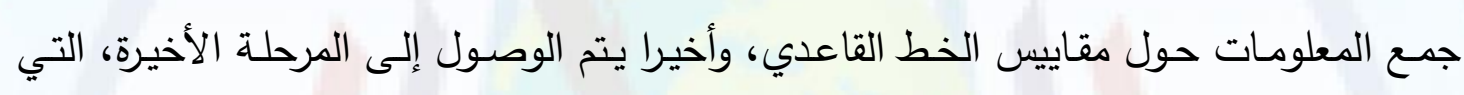
تهدف إلى تطبيق المسترشد للاستراتيجيات العلاجية. في ضوء هذه التعريفات تتبنى الباحثة تعريف مفهوم البرنامج المعرفي السلوكي بأنه

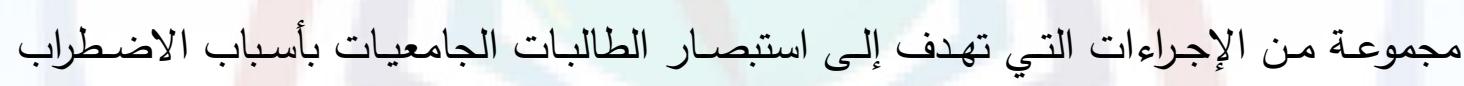

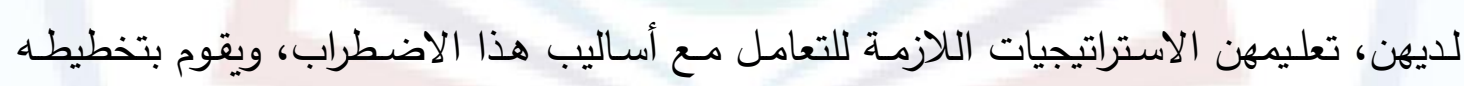
وتنفيذه وتقييمه لجنة وفريق من المسئولين المؤهلين. تعتمد الباحثة في الدراسة الراهنة لبناء برنامج إرشادي يقوم على فنيات العلاج المعرفي السلوكي

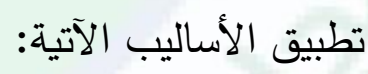

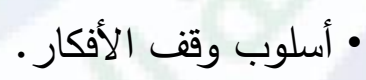

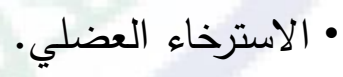

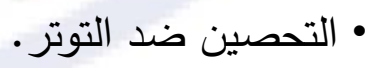

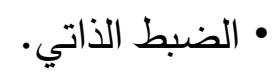




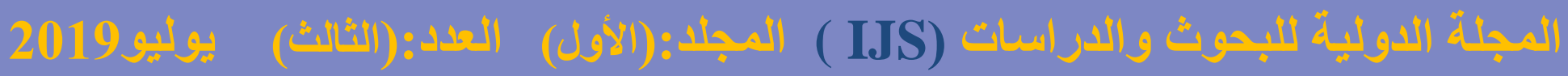

د. رانيا الصاوي عبده عبد القوي، (فاعلية برنامج إرشادي مقترح لخفض الوسواس القهري لاى طالبات الجامعة).

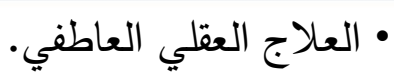

بحيث يمثل كل أسلوب محتوى جلسة من جلسات البرنامج، مما يؤدي إلى انطفائها التدريجي

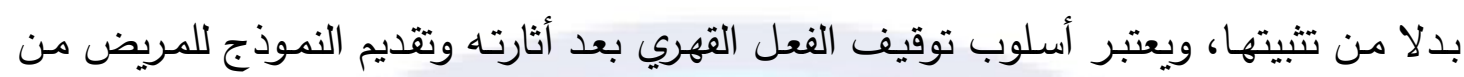
انجح الطرق مقارنة مع الطرق الأخرى، حيث يهدف إلى محاولة تغيير الأفكار الخاطئة، ذلك لك

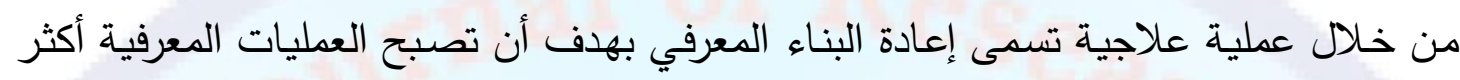
اتصالا بالواقع.

(3) الوسواس القهري Obsessive Compulsive:

يوضح المعجم الموسوعي في علم النفس(الوساوس) بأنه: فكرة أو عاطفة تفرض نفسها

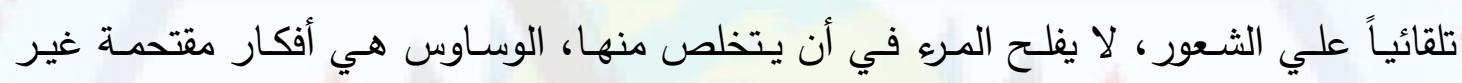

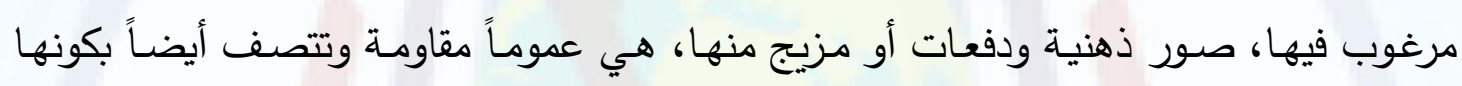
داخلية المنثأ، بينما الأفعال القهرية تتسم بالتكرار وتبدو في صورة سلوك عرضي وهي تمارس هربس أو تصاحب بإحساس ذاتي بالقهر يقاومها الثخص، وهي تمارس وفق قواعد معينة أو بطريقة نمطية علي الرغم من مقاومتها، فإن هذه السلوكيات تمارس بشكل نشط من جانب الثخص بهـ

$$
\text { (ليندزاي، وبول، } 2000 \text { :60-61). }
$$

كمـا يسـتخدم مصـطلحا الوسـواس والقهـري بشـكل تبـادلي غيـر دقيـق، كمـا يثـير كل مـن: ،(Nasayuki., Masahio \& Yashio, 2003-Greisberg, 2005 - Greer, 2005) والحقيقة هما يشيران إلى ظاهرتين مختلفتين، فالوساوس (obsessions) أفكار متسلطة تقتحم الفكر من داخله كما أنها تتكرر وتسبب ارتفاع في مستوى التوتر والقلق للفرد.

القهر (compulsion)، سلوك أو فعل جبري نمطي (جسمي أو عقلي) يظهر بقوة لدى المريض، ويلازمه ويستحوذ عليه، ويفرض نفسه عليه، ولا يستطيع مقاومته، رغم وعيه وتبَصُّره بغرابته وسخفه وعدم فائدته، ويشعر بالقلق والتوتر والاكتئاب إذا قاومها، ويشعر بإلحاح داخلي للقيام به، وبالتالي فهو يؤثر في حياة الفرد الاجتماعية وعلاقته مع الآخرين. 


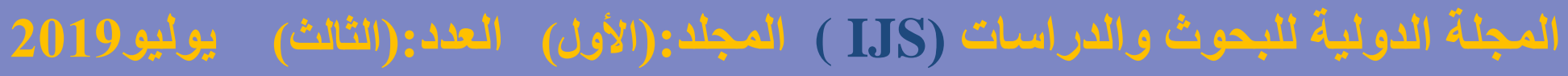

د. رانيا الصاوي عبده عبد القوي، (فاعلية برنامج إرشادي مقترح لخفض الوسواس القهري لاى طالبات الجامعة).

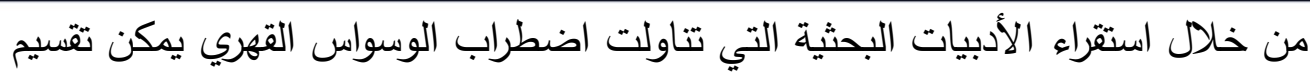

\section{أعراض الوساوس القهري إلى خمس فئات:}

1- الأفكار والصور (Ideas \& Images): سيطرة فكرة على الفرد محتواها مزعج أو صورة ذهنية غير مريحة لمنظر ما، أو جملة معينة غير مرغوبة تتردد على مخهه، أو نغمة موسيقية مزعجة متكررة ومستمرة في تفكيره.

2- الاندفاعات (Impulses): حيث يثعر الفرد بحدث مسيطر ، أو رغبة جامحة، أو اندفاعا لان يقوم بأعمال لا يرضى عنها، يحاول مقاومتها ولكن تسيطر عليه هذه الرغبة بقوة. 3- الطقوس الحركيـة (Rituals): سلوكيات متكررة ظاهريـة مثل: (غسيل الأيدي-الترتيبالفحص) أو تصرفات عقلية مثل:( العد، ترديد كلمات في صمت) يشعر الفرد بأنه مدفوع ومنقاد لأدائها بشكل متكرر وفقاً لقواعد صارمة. 4- المخـاوف القهريـة (Phobias): مرتبطة دائمـا بالأفكار ، أو الصور ، الاندفاعات والطقوس الحركية، بالتالي تكون وسيلة للهروب من الموقف القهري.

5- اجترار الأفكار (Ruminations): أفكار وأسئلة لا يمكن الإجابة عنها ويحاول المريض

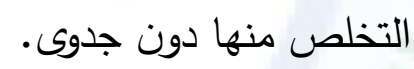

إجرائيا سوف تلتزم الدراسة الراهنة بمفهوم الوسواس القهري: بأنه الدرجة التي تحصل عليها الطالبة الجامعية على قائمة مودزلى للعصاب القهري (MOCl,Moudsley Obsessional Compulsive Inventory) للوسواس القهري (Yale-Brown Obsessive Compulsive Scale ,Y-BOCS) ترجمة (فرج، البشر : 2002). (فوسون) 


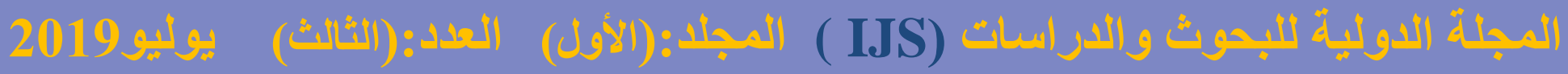

د. رانيا الصاوي عبده عبد القوي، (فاعلية برنامج إرشادي مقترح لخفض الوسواس القهري لاى طالبات الجامعة).

$$
\text { (ب) الدراسات السابقة: - (ب) }
$$

هناك العديد من الدراسات التي اهتمت ببرامج العلاج النفسي لاضطراب الوسواس

القهري. من هذه الدراسات دراسة سمير (2001) والتي هدفت إلى استكشاف فعالية العلاج العقلاني الانفعالي السلوكي في خفض مستوى الوساوس القهرية لاى عينة من طلاب الجامعة، للكثف عن الأفكار اللاعقلانية المسببة للوساوس القهرية لاى عينة الدراسة التي تكونت من (20) طالباً وطالبة من طلاب الجامعة، تم تقسيمهم إلى مجموعتين تجريبية وضابطة، أظهرت الدراسة فاعلية برنامج العلاج العقلاني الانفعالي السلوكي في تخفيف أعراض الوسواس القهري لاى عينة الدراسة وتعديل الأفكار اللاعقلانية لليهم.

كما قارنت دراسة McLea (2001) بين العلاج المعرفي السلوكي، والعلاج السلوكي باستخام فنية التعريض ومنع الاستجابة، في علاج الاضطراب الوسواسي القهري، حيث تكونت العينة من(64) مشاركاً ممن يعانون من اضطراب الوسواس القهري، تم تقسيمه إلى (32)

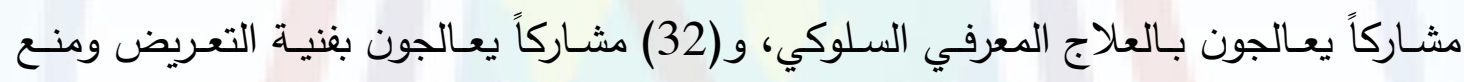

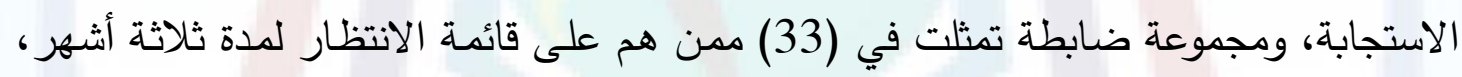
تراوحت أعمار العينة من(18: 56)، أظهرت الدراسة فاعلية كلٍ من برنامج العلاج المعرفي السلوكي، والعلاج السلوكي بفنية التعريض ومنع الاستجابة في تخفيف أعراض الوسواس القهري

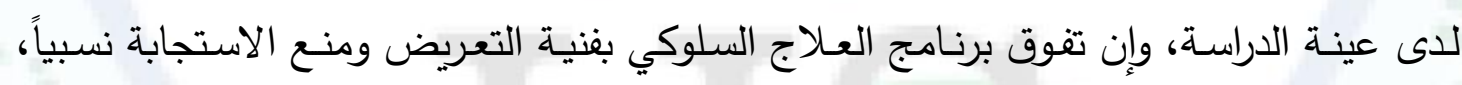

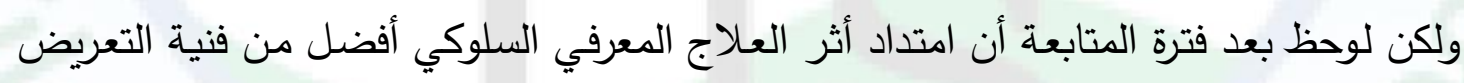
ومنع الاستجابة فقط.

كما كشفت دراسة (فرج والبشر) (2002) عن مدى كفاءة أسلوب العلاج السلوكي (بننية

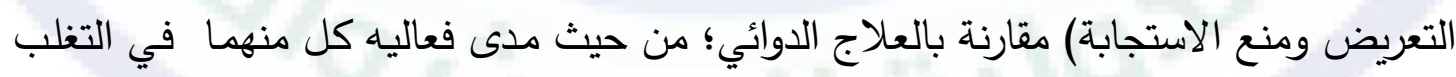
على أعراض الوسواس القهري، كما هدفت أيضا إلى تتييم كلا الأسلوبين معاً في مقابل استخدام

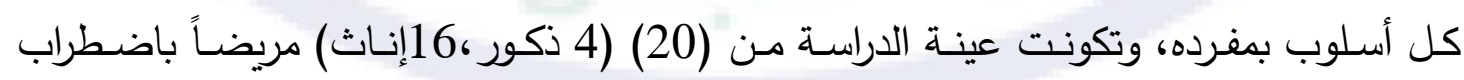

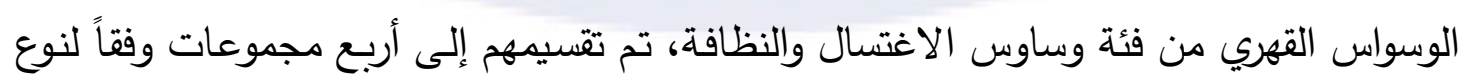

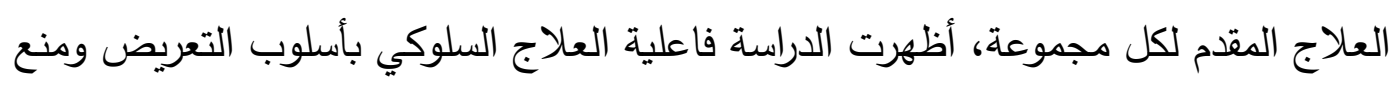




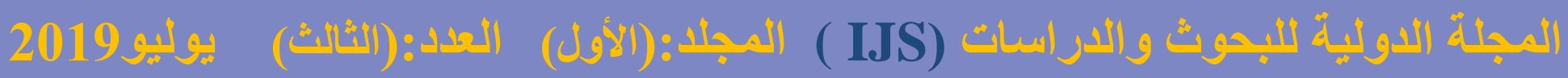

د. رانيا الصاوي عبده عبد القوي، (فاعلية برنامج إرشادي مقترح لخفض الوسواس القهري لاى طالبات الجامعة).

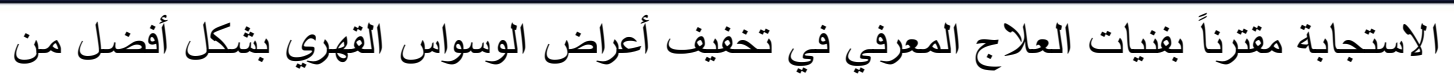
مجموعة العلاج الدوائي وحده، ومن مجموعة العلاج السلوكي وحده، بما يوفره العلاج السلوكي المعرفي من استبصار جيد بطبيعة الاضطراب وقدرة أكبر على منع الانتكاسة.

بينما سعت دراسـة (مبارك) (2004) إلى استكثـاف فاعلية برنـامج علاجي سلوكي شمولي أسرى مكثف مع حالة اضطراب وسواسي قهري مصحوب باضطرابات انفعالية (الخوف، الاكتئاب، القلق) تمثلت عينة الدراسة في دراسة حالة طفل عمره (12) عاما في بداية الصف علف عرئ الثاني الإعدادي يعاني من وساوس وشكوك متسلطة، وأفعال قهريـة، تدور أبرزها حول طقوس الاغتسال والنظافة والتلوث والمراجعة والعد والتكرار والبطء القهري ووساوس الصـلاة والطهارة.

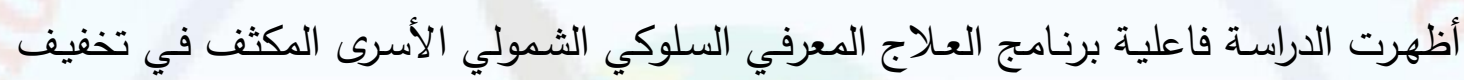
أعراض الوسواس القهري لدى الطفل بالتعاون مع أسرته.

كما هدفت دراسة Wilson \& Chambless المعرفي السلوكي مـع اضطراب الوسواس القهري، تكونت عينـة الدراسـة من (10) أفراد ممن يعانون مـن اضطراب الوسواس القهري، اعتمد البرنـامج على فنيات: إعـادة البنـاء المعرفي، الحوار ، الاسترخاء، وقف الأفكار ، التدريب على التعريض ومنع الاستجابة، الواجبات المنزلية، أوضحت نتائج الدراسة فاعلية برنامج العلاج المعرفي السلوكي المستخدم في التقليل من أعراض التصني الوسواس القهري، والتي تمثلت في: طقوس قهرية، مخاوف، وساوس عن النظافة، غلق الأبواب والإصابة بالأمراض.

وقد أجرىGreer(2005 دراسة حول فاعلية العلاج المعرفي السلوكي في خفض الوسواس القهري مستخدما استراتيجيه العلاج العقلي العاطفي كإستراتيجية ضمن الاستراتيجيات العلاجية في العلاج السلوكي المعرفي، تكونت عينـة الدراسـة (33) مشاركا ممن يعانون من اضطراب الوسواس القهري، وقد ركز العلاج المعرفي السلوكي في هذه الدراسة على المعتقدات الوظيفية الخاصة ودورها في نشوء الوسواس واستمراره، كما تم اخذ متغيرات في الدراسة كالاكتئاب والقلق، وأثـارت نتائج الدراسة إلى انخفاض واضـح في أعراض الوسواس القهري، كما حدث انخفاض واضح في القلق والاكتئاب. 


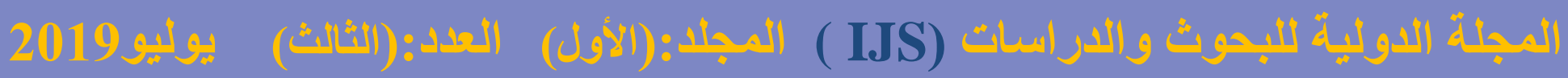

د. رانيا الصاوي عبده عبد القوي، (فاعلية برنامج إرشادي مقترح لخفض الوسواس القهري لاى طالبات الجامعة).

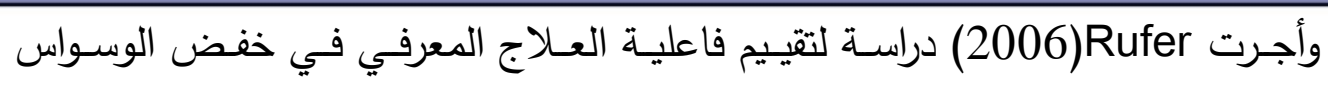

القهري، تكونت عينة الدراسة من (104) أفراد يعانون من اضطراب الوسواس القهري، حسب ما

صنفوا في الاختبارات الكلية، أشارت النتائج إلى فاعلية العلاج السلوكي المعرفي وخصوصا في لتراي

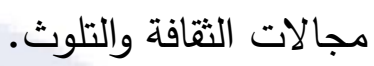

أيضـا هدفت دراسـة2007)Tolin,ets) إلى اختبار فاعلية برنـامج إرشادي في العـلاج

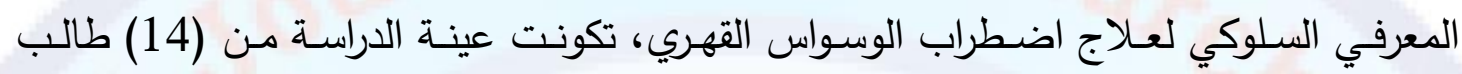
جامعي ممن يعـانون من اضطراب الوسواس القهري، تتراوح أعمارهم بين (13: 22 عامـا)،

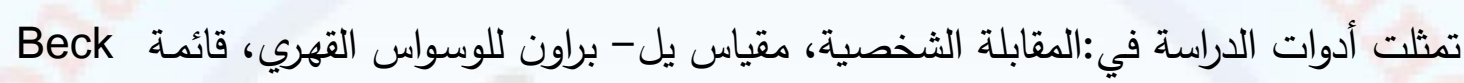
Depression Inventory-II البرنامج على (26) جلسة إرشادية معرفية سلوكية، أظهرت نتائج الدراسة وجود فروق ذات دلالة إحصائية لصالح المجموعة التجريبية في خفض أعراض الوسواس القهري، مما يشير إلى فاعلية

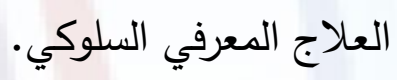

وأخيرا استهدفت دراسة (فرحان) (2008) إلى فحص اثر فاعلية برنامج إرشاد جمعي معرفي سلوكي في خفض الوسواس القهري للى عينة من طلبة جامعة آل البيت، تكونت عينة الدراسة من (20) طالبا تم تقسيمهم إلى مجموعتين ضـابطة وتجريبية، وتكون البرنامج العلاجي من (12) جلسة لتطوير مهاراتهم على استخدام الإجراءات المعرفية السلوكية في التعامل مـع لـع الوسواس القهري، وخلصت النتائج إلى فاعلية البرنامج الإششادي في خفض اضطراب الوسواس القهري.

ملاحظات الباحثة على الدراسات السابقة وموقع الدراسة الراهنة منها:

1. لاحظت الباحثة أن أدوات الدراسـة الأكثر استخداماً وفاعليـة هـي: مقيـاس يـل - بـراون للوسواس القهري لفائدته في قياس درجـة وشدة الاضطراب، وقائمسة مودزلى للوساوس القهريـة كأهم الأدوات التثخيصية.

2. كما لاحظت الباحثة أن عدد الجلسات لا ينبغي أن يقل عن عشر جلسات، بل وربما تزيد

إلى عشرين جلسة، وتتراوح مدة كل جلسة مابين (120:40 دقيقة). 


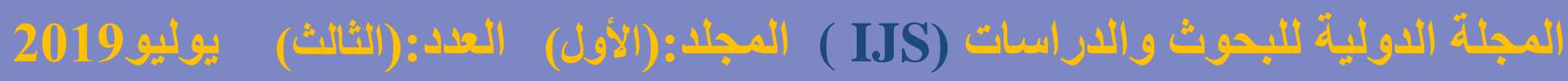

د. رانيا الصاوي عبده عبد القوي، (فاعلية برنامج إرشادي مقترح لذفض الوسواس القهري لاى طالبات الجامعة).

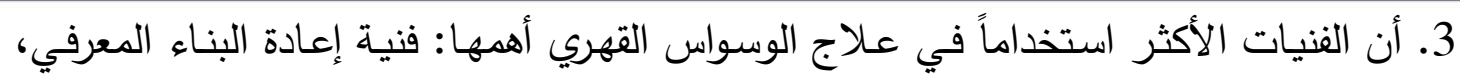

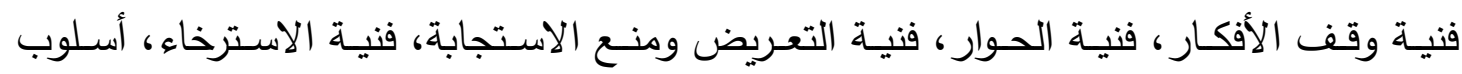

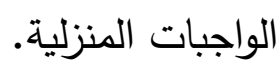

مما سبق يمكن القول أن ثمة إضافات يمكن اعتبارها إضافة للتراث المعرفي بدراسة فاعلية برنـامج إرشـاد جمسي باستخدام فنيات العـلاج المعرفي السلوكي في خفض الوسواس إس القهري لاى عينة من طالبات الجامعة، أولى هذه الإضـافات هي قيام الباحثة بتصميم برنامج علاجي تراعي فيـه السمات والخصـائص التي تميز مجتهـع البحث في ضـوه الفنيـات الآتيـة (أسلوب وقف الأفكار، الاسترخاء العضلي، التحصين ضد التوتر ، الضبط الذاتي، أسلوب حل المشكلات وعلاج العقلي العاطفي)، هذا مـا يحدد موقع الدراسـة الراهنـة من خريطـة الدراسـات

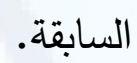
سادسا: الإجراءات المنهجية للدارسة: (أ) منهج الدراسة:

استخدمت الدراسة المنهج التجريبي معتمدة على التصميم التجريبي ذو المجموعتين (قبلي، بعدي)، بهدف اختبار فاعلية برنـامج إشـادي مقترح لخفض الوسواس القهري لدى عينـة من طالبات الجامعة، واشتملت الدراسة على المتغيرات التالية:

- متفيرات تجريبية: تتمثل في تقديم البرنامج الإرشادي الجمعي الذي يعتمد على فنيات العلاج المعرفي السلوكي لخفض الوسواس القهري للى عينة من طالبات الجامعة (المجموعة التجريبية)، أو عدم تقديم البرنامج الإرشادي لطالبات (المجموعة الضابطة).

- المتغيرات التابعة: تتمثل في المتغيرات الناتجة عن البرنامج الإرشادي الجمعي الذي يعتمد على فنيات العلاج المعرفي السلوكي لخفض الوسواس القهري لدى عينة من طالبات الجامعة. (ب) عينة الاراسة: (ب) - (ب)

نظرا لطبيعة المنهج المستخدم (التجريبي) فإن عينة الدراسة وقعت ضمن نطاق العينة العشوائية البسيطة، وتم سحب مفرداتها بطريقة الجداول الإحصائية من طالبات الفرقة الثانية International Journal of Research and Studies (ijs) It is issued by the Excellence Pioneers Academy 


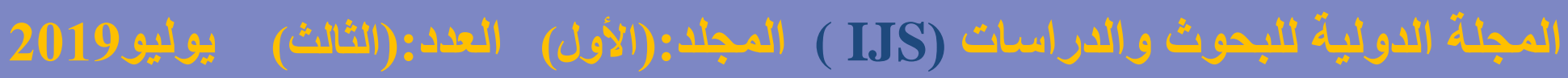

د. رانيا الصاوي عبده عبد القوي، (فاعلية برنامج إرشادي مقترح لخفض الوسواس القهري لاى طالبات الجامعة).

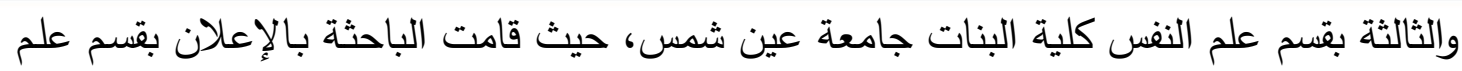
النفس كلية البنات جامعة عين شمس عن متطوعين للاشتراك ببرنامج علاجي ينعكس إيجابيا عليهن في خفض بعض الأفكار والأفعال التي تسيطر عليهن ولا تستطعن السيطرة عليها بالرغم من معرفتهن بسخافة هذه الأفكار والأفعال، تم التقدم للاشتراك بالبرنامج (70) طالبة، تم تطبيق قائمسة (MOCl,Moudsley Obsessional Compulsive Inventory) (ترجمة فرج Yale-Brown Obsessive Compulsive Scale) (Y- ملحق1، مقياس) (2002، والبشر)

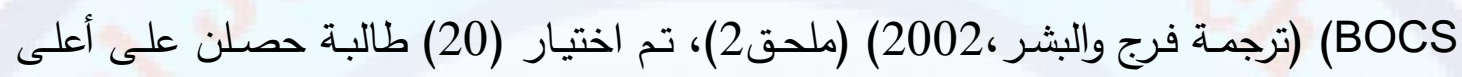
درجات على مقياس اضطراب للوسواس القهري، تراوحت درجاتهم بين (122-160) شكلّوا عينة

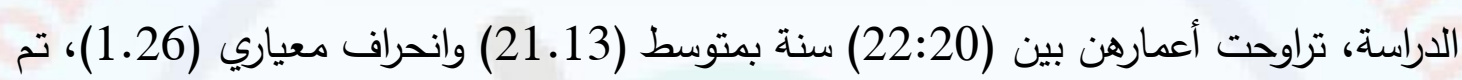
تقسيمهن إلى مجموعتين متجانستين مجموعة تجريبية ومجموعة ضابطة، تتلقى أفراد المجموعة

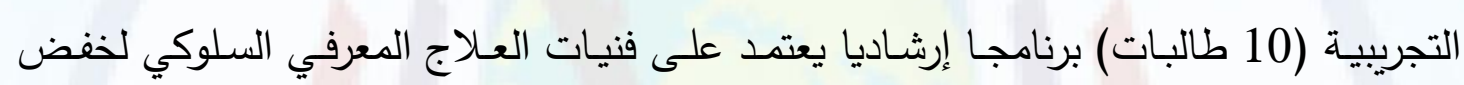
الوسواس القهري التقت بهم الباحثة بمعدل جلستين بالأسبوع، لمدة ستة أسابيع، مدة كل جلسة (ساعة وقد تمتد إلى الساعة والنصف)، وتكونت العينة الضابطة (10 طالبات) لم تتلقى إحداهن أي برنامجا إرشاديا.

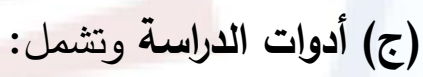

1 - قائمة المودزلي للوسواس القهري (ترجمة فرج والبشر،2002)

(MOCl,Moudsley Obsessional Compulsive Inventory)

تتـألف القائعـة مـن (30) عبـارة تقيس مجموعـة مـن الأفكار الوسواسية والأفعـال

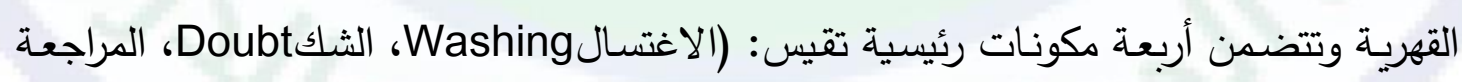

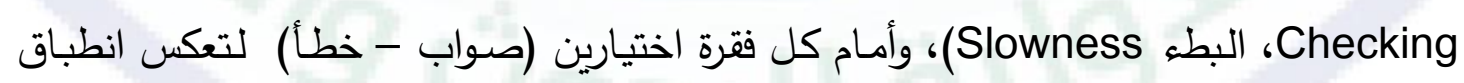
العبارة على الطالبة، قامت الباحثة بالتحقق من صدق القائمسة من خـلال الصدق الظـاهري،

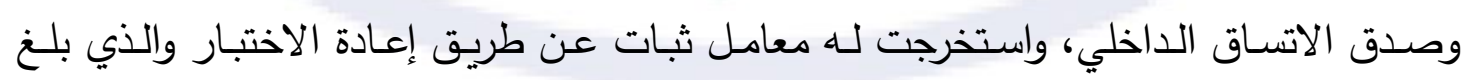

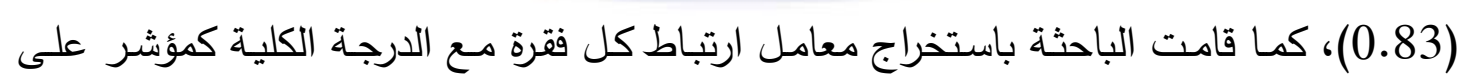

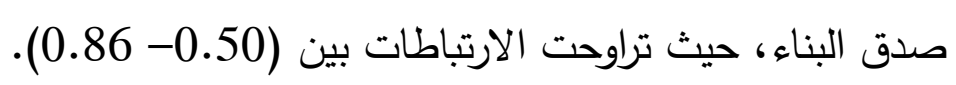




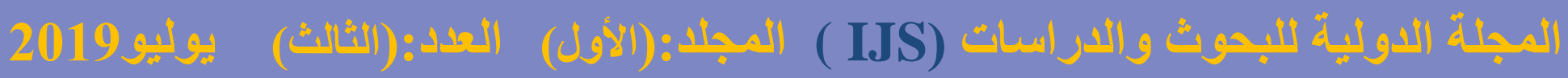

د. رانيا الصاوي عبده عبد القوي، (فاعلية برنامج إرشادي مقترح لخفض الوسواس القهري لاى طالبات الجامعة).

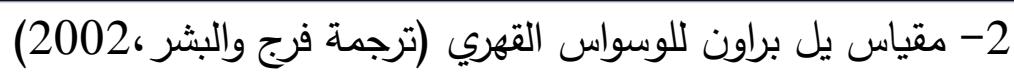

(Y-BOCS, Yale-Brown Obsessive Compulsive Scale)

مقياس يل براون للوسـاوس القهريـة وضعـه جودمـان وآخرون عام(1989)،كأداة

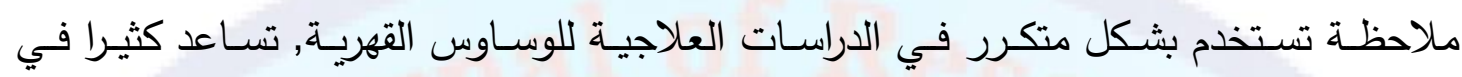
استخراج مالم يذكره المريض، ومالم يعتقد أنه ذو علاقة بالأمر في حياته، ويهدف تطبيقه على لى لئل

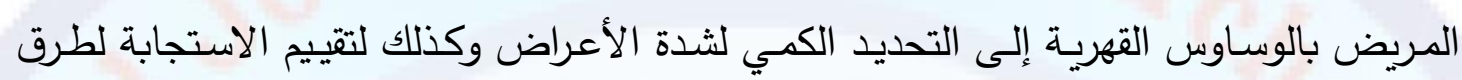
العلاج المختلفة، وذلك من خلال تقييم الطبيب النفسي أو الاختصاصي النفسي لعدة متغيرات

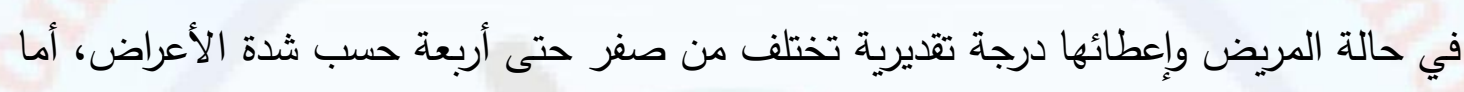
بدائل الاستجابة فإنها خماسية وفق طريقة ليكرت (يحدث لدي باستمرار - يحدث لدي كثيرا-

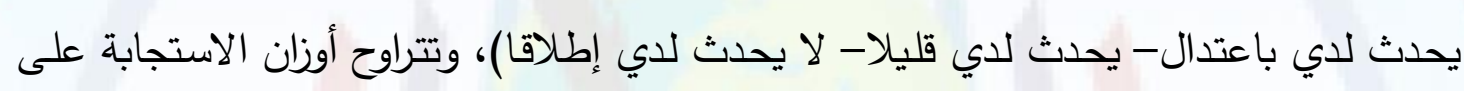

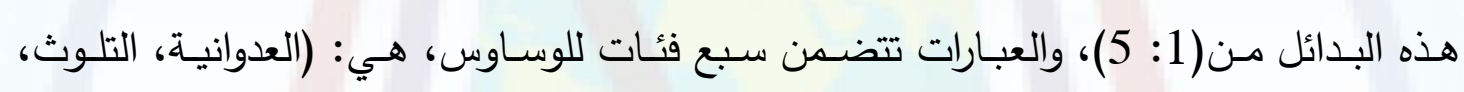

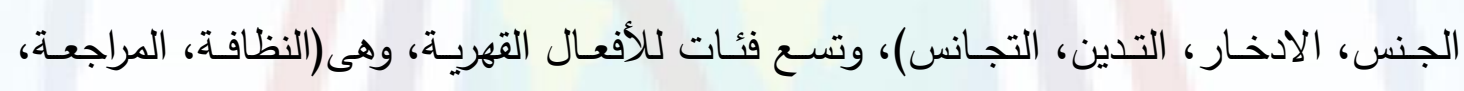
التكرار، العد، الترتيب، الاختزان، اللمس، الطقوس العقلية).

قامت الباحثة بحساب الاتساق الداخلي بين الفقرات بطريقة الارتباط بين درجة الفقرة

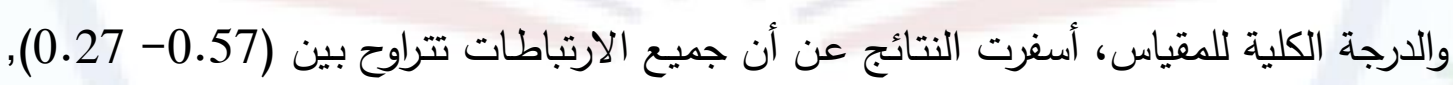

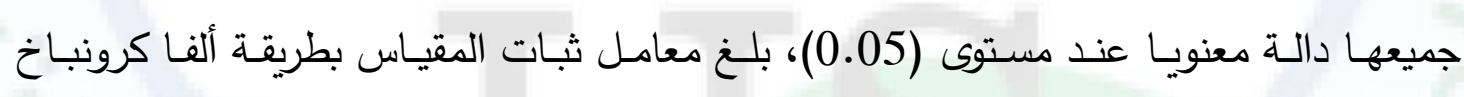

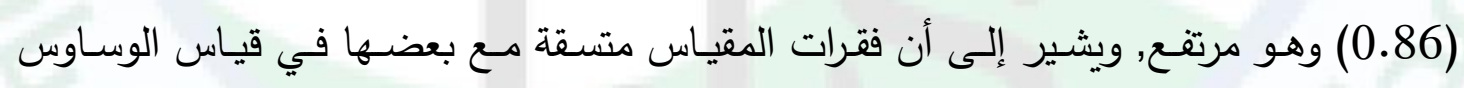
القهربية.

$$
3 \text { - البرنامج المقترح: (إعداد: الباحثة): }
$$

تلقت مجموعـة مـن الطالبـات الجامعيات (المجموعـة التجريبيـة) برنامجـا إشـاديا معرفيا سلوكيا بهدف خفض اضطراب الوسواس القهري، فقد تكون البرنامج من (12) جلسة إرشادية

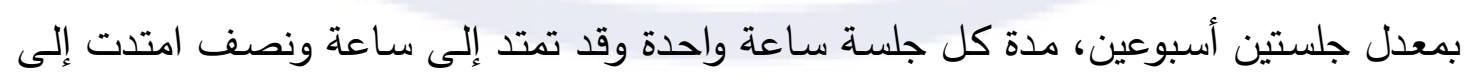
ستة أسابيع، وجلسة واحدة لأغراض تطبيق القياس البعدي، تم توظيف كل جلسة أسلوبا معرفيا سلوكيا، ثم قامت الباحثة بإجراء الصدق الظاهري للبرنامج وعرضسه على خمسة من المحكمين 


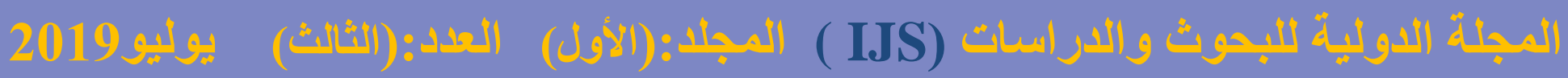

د. رانيا الصاوي عبده عبد القوي، (فاعلية برنامج إرشادي مقترح لخفض الوسواس القهري لاى طالبات الجامعة).

ملحق (3) المختصين في علم النفس والعلاج النفسي، لمعرفة آرائهم في مدى مناسبة البرنامج للأهـداف والمهارات المستخدمة للتدريب، ومـدة تطبيـق البرنـامج، ثم قامـت الباحثـة بـإجراء التعديلات التي طرحها المحكمين والاستفادة من المقترحات التي قدموها للبحث.

مصادر بناء البرنامج:

1- من خـلال استعراض الدراسـات السابقة والأدبيات السيكولوجية التي تتاولت برامج العـلاج النفسي المعرفي السلوكي للوسواس القهري، من أمثلتها:

•برنامج العلاج العقلاني الانفعالي السلوكي في خفض مستوى الوساوس القهرية لاى عينة من طلاب الجامعة. إعداد :(سمير : (2001).

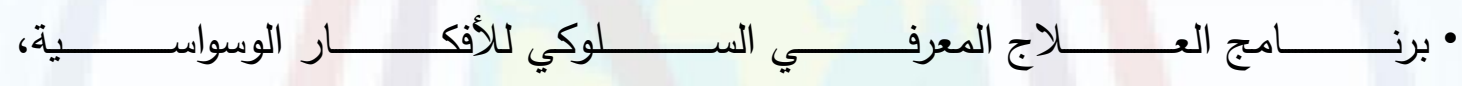
(Freeston,Loger,\&Ladouceur,2001):إعداد • برنـامج العـلاج المعرفي السـلوكي الجمـاعي لاضـطراب الوسـواس القهري إعداد: (2001, .(McLean • برنامج العـلاج السلوكي بفنية التعريض ومنع الاستجابة لاضطراب الوسواس القهري، إعداد: .(McLean,2001) • برنامج العلاج السلوكي لمرضى الوسواس القهري، إعداد: فرج والبشر (2002). • برنامج العلاج المعرفي السلوكي المكثف لاضطراب الوسواس القهري المصحوب باضطرابات

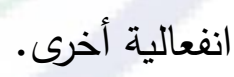
إعداد: مبارك (2004). • برنامج العلاج المعرفي لاضطراب الوسواس القهري، إعداد: .(Wilson,\& Chambless, 2005)

\section{International Journal of Research and Studies (ijs) It is issued by the Excellence Pioneers Academy}




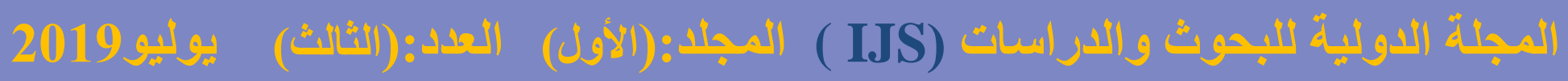

د. رانيا الصاوي عبده عبد القوي، (فاعلية برنامج إرشادي مقترح لخفض الوسواس القهري لاى طالبات الجامعة).

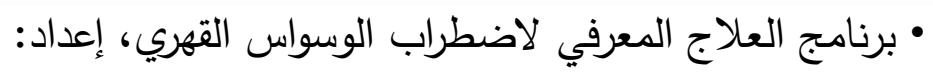

.(Wilhelm, S,\& Steketee,2005)

• برنامج العلاج المعرفي السلوكي المدمج بفنية التعريض ومنع الاستجابة، إعداد:

.(Himle et al ,2006)

• برنامج العلاج المعرفي السلوكي الفردي والجماعي لاضطراب الوسواس القهري،

إعداد: (Anderson,\& Rees,2007).

• برنامج العلاج المعرفي السلوكي المتخصص في مقاومة اضطراب الوسواس القهري.

إعداد:(Sookman, \& Steketee, G.,2007).

• برنامج قائم على استراتيجيات ما وراء المعرفة في خفض اضطراب الوسواس القهري، إعداد عبد الظاهر (2008).

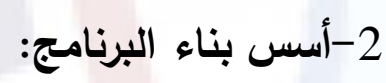

أ- تهيئة جو من الثقة، وتقدير قدرات وجوانب النجاح لاى الطالبات اللاتي تخضعن للبرنامج،

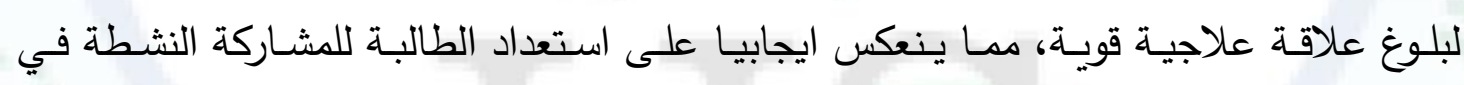
الجلسات العلاجية وأداء الواجبات المنزلية.

ب- الحرص على تكرار وإعادة عرض فنيات العلاج بأكثر من طريقة وعدم الانتقال من نقطة إلى أخرى إلا بعد التأكد من انتهاء النقطة الأولى، والتغلب على أعراض الوسواس القهري الواحد

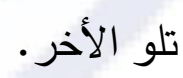

ت- الاستفادة من فنيات العلاج الجماعي من خلال مساعدة الطالبات على التحسن في إطار

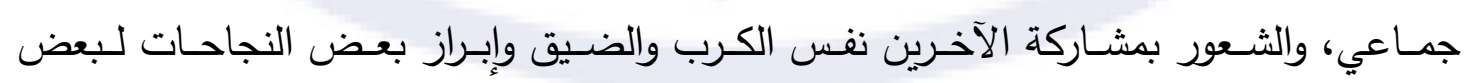




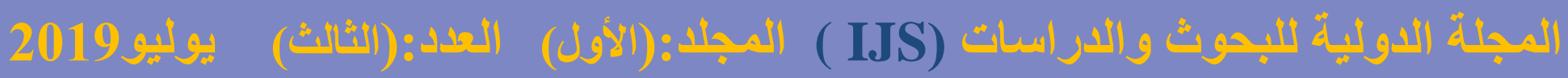

د. رانيا الصاوي عبده عبد القوي، (فاعلية برنامج إرشادي مقترح لخفض الوسواس القهري لاى طالبات الجامعة).

ث- مناقشتة الطالبات فيما تم التدريب عليه أثتاء الجلسـة العلاجية، طلب ملخص منهن عقب إب الانتهاء من ممارسـة التدريب على كل فنية من فنيات العلاج النفسي المعرفي السلوكي خلال الجلسات لبلوغ الاستبصار الذاتي لديهن.

ج- استخدام أسلوب التعزيز الإيجابي والتشجيع من جانب الباحثة للطالبات عندما تأتي أحدهن بالاستجابة المناسبة، وأداء التدريب بكفاءة.

ح- مراعاة اشتمال البرنامج على أنشطة ترويحية أو فترات انتقالية للتخفيف من وطأة الضغط النفسي والتخفيف عن الطالبات بما يتلاءم مع طبيعة الجلسات وطبيعة شخصية الطالبات ودرجة تجاوبهن مع الباحثة وفى ذلك كسر لحاجز الريبة ودعم لعلاقات الثقة والود على مدار الجلسات.

خ- استخدام أسـلوب الواجبات المنزليـة للتأكد مـن نجـاح التدريب داخل الجلســة وقيام الطالبـة بالمشـاركة النشطة، لتحديد بـايات الجلسـة التاليـة ودرجـة وشـدة الاضـراب وجدولـة الأعراض الوسواسية والقهرية للتخفيف منها.

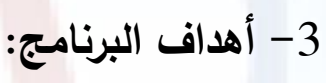

يهدف البرنامج إلى إكساب طالبات المرحلة الجامعية مجموعة من المهارات السلوكية والمعرفيـة التي تؤهلهن للتوافق مـع أنفسهن ومـع البيئـة اللاتـي يعشـن فيهـا، لمعرفـة الأفكـار الوسواسية والتنفيس عن الانفعالات المكبوتة المصاحبة لها والاستبصار بها (إذا عرف الإنسان السـبب الكـامن وراء سـلوك معين أو لازمــة محـددة يمكـن بمسـاعدة المرشـــ أن يتخلى عنهـا بالتدريج)، يتمثل الهدف الإجرائي الرئيس خفض أعراض الوسواس القهري لدى عينة الدراسـة من طالبات الجامعة، وذلك من خلال بعض فنيات العلاج النفسي السلوكي المعرفي، يتمثل التحقيق الإجرائي لهذا الهدف انخفاض متوسط درجات أفراد المجموعة التجربيية عن المجموعة الضـابطة في قائمة مودزلى للعصاب القهري، بعد تطبيق البرنامج؛ كذلك انخفاض درجات القياس البعدي عن درجـات القياس القبلي، لنفس المجموعـة التجريبية على قائمـة مودزلى للعصـاب القهري، ومقياس يل - براون للوسواس القهري، مما يساعدهن على زيادة الثقة بأنفسهن واعتمادهن على أنفسهن وضـبط انفعـالاتهن، وزيـادة تفاعلاتهن الاجتماعيـة وإكسابهن عـادات ومهارات صـحية

سليمة.

\section{International Journal of Research and Studies (ijs) It is issued by the Excellence Pioneers Academy}




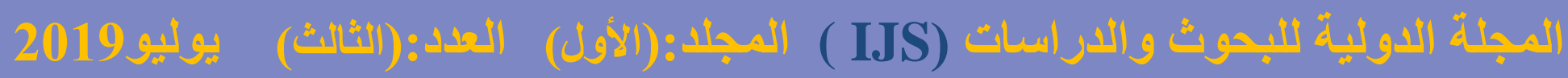
د. رانيا الصاوي عبده عبد القوي، (فاعلية برنامج إرشادي مقترح لذفض الوسواس القهري لاى طالبات الجامعة).

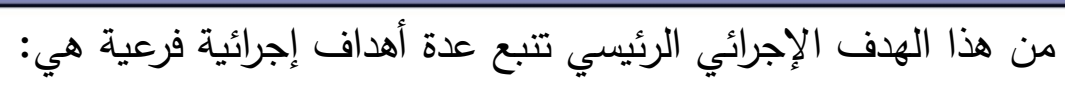

1- تخفيف أعراض الوسواس القهري المتمثلة في وساوس المراجعة، التكرار والعد.

2- تخفيف أعراض الوسواس القهري المتمثلة في وساوس البطه، الطقوس العقلية، التخزين

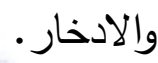

3- تخفيف أعراض الوسواس القهري المتمثلة في وساوس التلوث، اللمس والاغتسال.

$$
4 \text { - الأساليب والفنيات المستخدمة في البرنامج: }
$$

تتاولت الباحثة الفنيات والأساليب الآتية:(فنية وقف الأفكار - فنيـة إعادة البناء المعرفي- فنية التعريض ومنع الاستجابة- فنية التحصين التدريجي -فنية صرف الانتباه-فنية لعب الدور - فنية

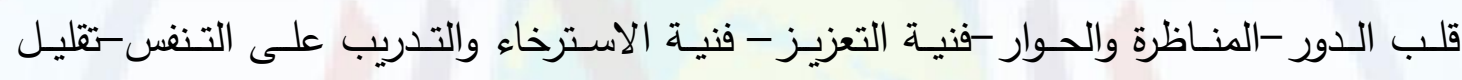
الحساسية التدريجي-أسلوب المحاضرة-أسلوب المناقثة الجماعية-الواجبات المنزلية).

\section{5- 5 - الحدود الإجرائية للبرنامج:}

أ- الحدود الزمنية: يتم تتفيذ البرنامج على مدى ستة أسابيع، بواقع جلستين أسبوعياً، بمجموع

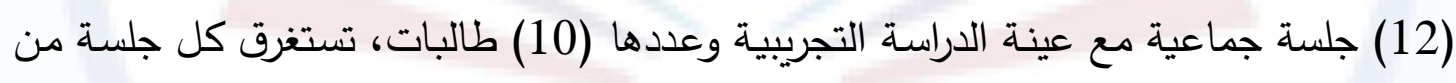
ساعة إلى ساعة ونصف تقريبا. ب- الحدود المكانيـة: تم تنفيذ البرنامج بغرفة الاستثـارات النفسية بكلية البنات جامعة عين شمس.

ج- الحـدود البثـرية: تم تتفيذ البرنـامج على عينـة مـن الطالبـات ذوات اضطراب الوسـواس القهري، قوامها (10) طالبات ممن تتراوح أعمارهن بين (20-22) سنة، في ضوه هذه البرامج، الإطار النظري، الدراسات السابقة، مبادئ وخطوات إرشاد جمعي معرفي سلوكي قامت الباحثة بإعداد البرنامج وتحكيمه ثم مراجعته وتنفيذه. 


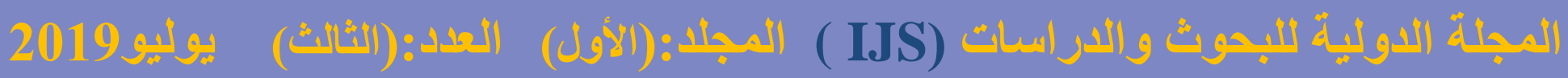

د. رانيا الصاوي عبده عبد القوي، (فاعلية برنامج إرشادي مقترح لخفض الوسواس القهري لاى طالبات الجامعة).

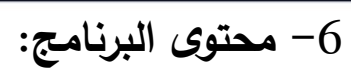

تم توزيع محتوى البرنامج المعرفي السلوكي لخفض اضطراب الوسواس القهري لطالبات

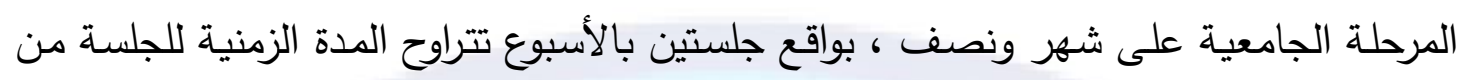
ساعة إلى ساعة ونصف تقريبا، بحيث تثمل كل جلسة على مهارات سلوكية ومعرفية لخفض

$$
\text { اضطراب الوسواس القهري (ملحق 4). }
$$

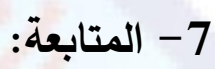

تعني المتابعة المعرفة العلمية المنظمة لمدى الثبات والاستمرار في تحسن الأعراض النفسية والسلوكية والمعرفيـة التي حدثت لأفراد العينـة التجريبيـة بعد فتـرة زمنيـة (شهـر ) من البرنـامج الإرشادي (التطبيق التتبعي) وهي جلسة متابعة.

الهدف منها هو التأكد من ثبات التحسن وتحديد نسبة التقدم ومدى استفادة الطالبة الجامعية من البرنامج التدريبي وتعزيز التغيرات الايجابية في سلوك الطالبة الجامعية منعا من انتكاسها، وتقديم العون للجوانب الأخرى التي هي بحاجة إلى مساعدة لتعزيز الثبات، والفائدة منها هي

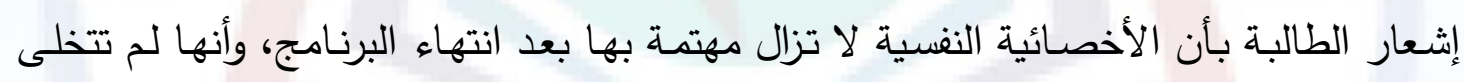

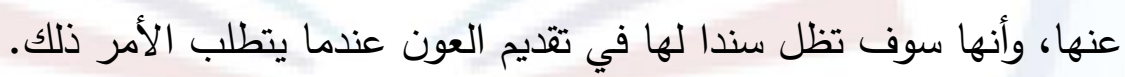
8- - إجراءات التطبيق: تم تقييم البرنامج عن طريق القياس القبلي أي قبل تطبيق إجراءات البرنامج حيث تم

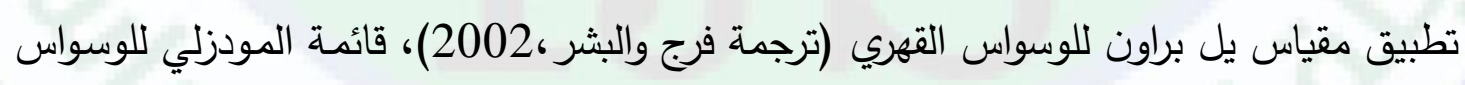
القهري (ترجمة فرج والبشر، 2002) ،وعن طريق القياس البعدي أي بعد انتهاء البرنامج طبقت

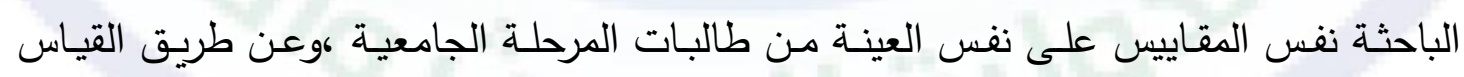
التتبعي بعد فترة متابعة لمدة شهر طبقت الباحثة نفس المقاييس على نفس العينة من طالبات المرحلة الجامعية. 


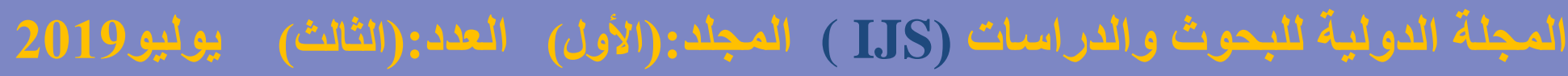
د. دانيا الصاوي عبده عبد القوي، (فاعلية برنامج إرشادي مقترح لذفض الوسواس القهري لاى طالبات الجامعة).

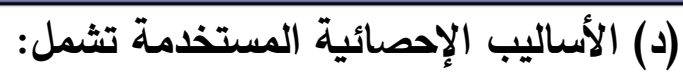

استخدمت الباحثة برنـامج الحزمـة الإحصـائية للعلوم الإنسانية (SPSS) وذلك

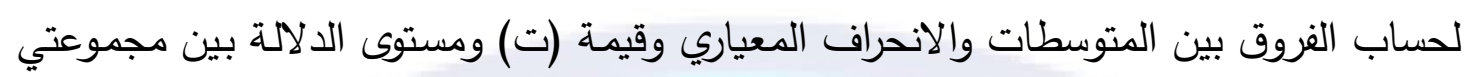
الدراسة.

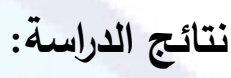

سوف تعرض الباحثة النتائج التي تم التوصل إليها من خلال الأساليب الإحصائية التي

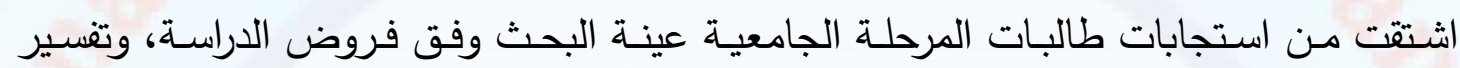
النتائج في ضوء الإطار النظري للدراسة الراهنة.

لللتأكد من صحة الفرض الأول والذي ينص على: توجد فروق دالة إحصائيا في الدرجة الكلية لدقياس يل براون للوسواس القري بين طالبات المرحلة الجامعية (العينة التجريبية)

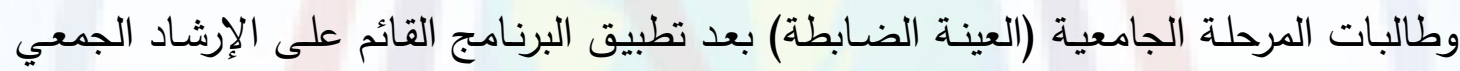
المعرفي السلوكي لصالح المجموعة التجريبية.

للتحقق من هذا الفرض تم دراسة الفروق بين المجموعة التجريبية والمجموعة الضابطة على الدرجة الكلية لدقياس الوسواس القهري يل براون (ترجمة فرج والبشر، 2002)، بعد تطبيق

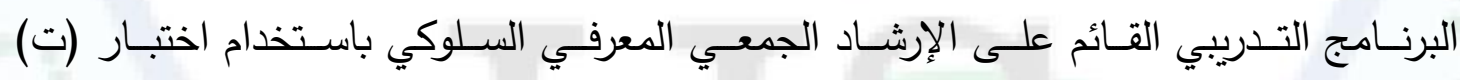
للمجموعات الصغيرة للالالة الفروق بين المتوسطات، والجدول التالي يوضح ذلك:

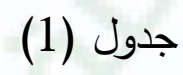

نتائج حساب قيمة "ت" لمتوسطي درجات الدجموعتين التجريبية والضابطة على الدرجة الكلية لمقياس يل براون للوسواس القهري بعد تطبيق البرنامج. 


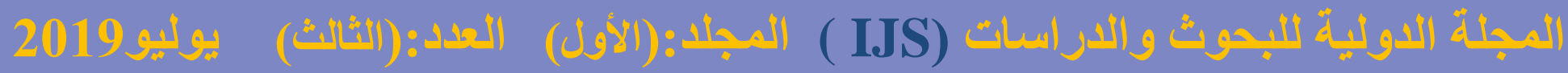
د. رانيا الصاوي عبده عبد القوي، (فاعلية برنامج إرشادي مقترح لذفض الوسواس القهري لاى طالبات الجامعة).

\begin{tabular}{|c|c|c|c|c|c|c|}
\hline & الدلالة & ت & $\varepsilon$ & م & ن & المجموعة \\
\hline 0.01 & 0.05 & 32.67 & 0.94 & 4.7 & 10 & التجريبية \\
\hline 2.552 & 1.734 & & 0.78 & 29.11 & 10 & الضابطة \\
\hline عنــــ مسـتوى & 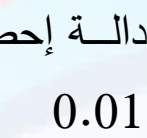 & & & & & \\
\hline
\end{tabular}

يتضـح مـن الجدول (1) أنـه توجد فرق دال إحصـائياً، عند مستوى (0.01)، بين متوسطيّ درجات المجموعتين التجريبية والضابطة على الدرجة الكلية لمقياس يل براون للوسواس القهري

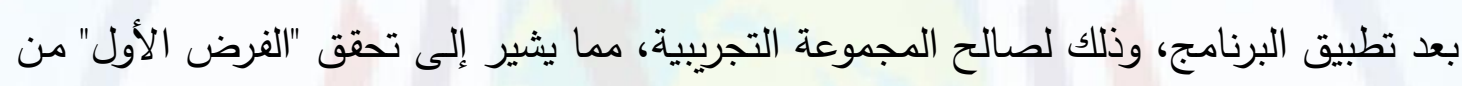
فروض الدراسة.

للتأكد من صحة الفرض الثاني والذي ينص على: توجد فروق دالة إحصـائيا في الدرجة الكلية لقائمة المودزلي للوسواس القهري بين طالبات المرحلة الجامعية (العينة التجريبية)

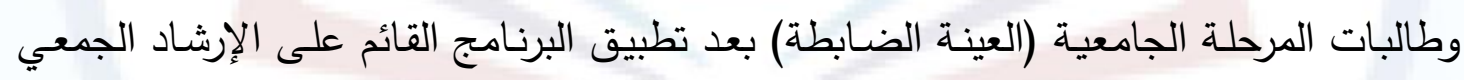
المعرفي السلوكي لصالح المجموعة التجريبية .

للتحقق من هذا الفرض تم دراسة الفروق بين المجموعة التجريبية والمجموعة الضابطة على الدرجة لقائمة المودزلي للوسواس القهري (ترجمة فرج والبشر، 2002)، بعد تطبيق البرنامج التدريبي القائم على الإرشاد الجمعي المعرفي السلوكي باستخدام اختبار (ت) لدلالة الفروق بين لين

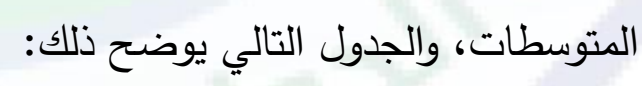

جدول (2)

نتائج حساب قيمة "ت" لمتوسطي درجات المجموعتين التجريبية والضابطة على الدرجة الكلية لقائمة المودزلي للوسواس القهري بعد تطبيق البرنامج.

International Journal of Research and Studies (ijs) It is issued by the Excellence Pioneers Academy 


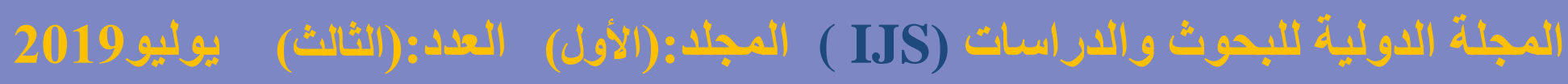

د. رانيا الصاوي عبده عبد القوي، (فاعلية برنامج إرشادي مقترح لذفض الوسواس القهي لاى طالبات الجامعة).

\begin{tabular}{|c|c|c|c|c|c|c|}
\hline & الدلالة & ت & $\varepsilon$ & r & ن & المجموعة \\
\hline 0.01 & 0.05 & 32.85 & 0.91 & 4.2 & 10 & التجريبية \\
\hline 2.564 & 1.624 & & 0.73 & 28.11 & 10 & الضابطة \\
\hline كنــــــــــتوى & دالـــة إد & & & & & \\
\hline & 0.01 & & & & & \\
\hline
\end{tabular}

يتضـح من الجدول (2) أنه توجد فرق دال إحصائياً، عند مستوى (0.01)، بين متوسطيّ درجات المجموعتين التجريبية والضابطة على الدرجة الكلية لقائمة المودزلي للوسواس القهري بعد تطبيق البرنـامج وذلك لصـالح المجموعة التجريبية، مما يشير إلى تحقق "الفرض

$$
\text { الثاني" من فروض الدراسة. }
$$

للتأكد من صحة الفرض الثالث والذي ينص على: توجد فروق دالة إحصائيا في الدرجة

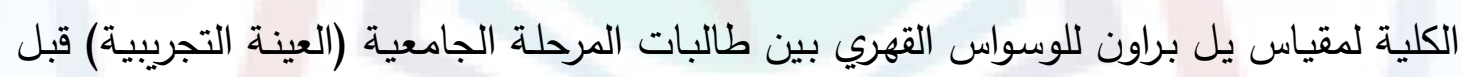

وبعد تطبيق البرنامج القائم على الإششاد الجمعي المعرفي السلوكي لصالح القياس البعدي ـ للتحقق من هذا الفرض تم دراسة الفروق بين المجموعة التجريبية قبل تطبيق البرنامج الترسيج وبعد تطبيقه على الدرجة الكلية لمقياس الوسواس القهري يل براون (ترجمة فرج والبشر، 2002) قبل تطبيق البرنامج وبعد تطبيقه القائم على الإرشاد الجمعي المعرفي السلوكي باستخدام اختبار (ت) لدلالة الفروق بين المتوسطات، والجدول التالي يوضح ذلك:

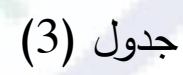

نتائج حساب قيمة "ت" لمتوسطي درجات المجموعة التجريبية على مقياس يل براون للوسواس القهري، قبل تطبيق البرنامج وبعد تطبيقه: 


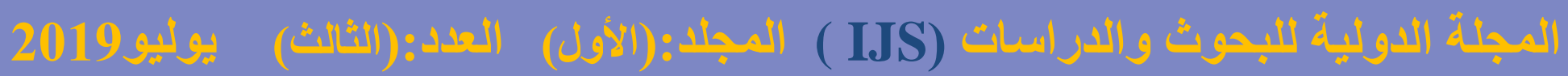
د. رانيا الصاوي عبده عبد القوي، (فاعلية برنامج إرشادي مقترح لخفض الوسواس القهري لاى طالبات الجامعة).

\begin{tabular}{|c|c|c|c|c|c|c|}
\hline & الدلالة & ت & $\varepsilon$ & ? & ن & المجموعة \\
\hline 0.01 & 0.05 & 36.64 & 0.72 & 26.78 & 10 & التجريبيـــــة قبـــلـ \\
\hline 2.82 & 1.83 & & 0.94 & 4.7 & 10 & 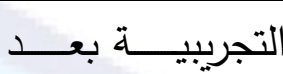 \\
\hline كنــد مسـتوز & دالـة & & & & & البرنامج \\
\hline & 0.01 & & & & & \\
\hline
\end{tabular}

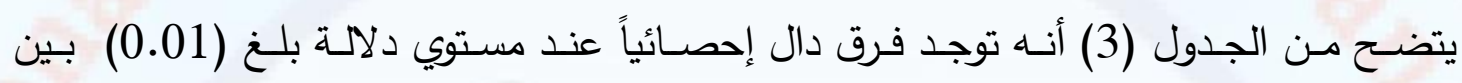
متوسطيّ درجات القياسين القبلي والبعدي، للمجموعة التجريبية، على مقياس يل براون للوسواس القهري، مما يشير إلى تحقق (الفرض الثالث) من فروض الدراسة.

للتأكد من صحة الفرض الرابع والذي ينص على: توجد فروق دالة إحصائيا في الدرجة الكلية

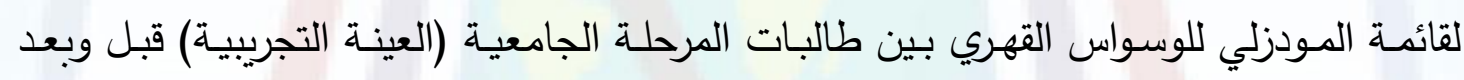
تطبيق البرنامج القائم على الإرشاد الجمعي المعرفي السلوكي لصالح القياس البعدي •

للتحقق من هذا الفرض تم دراسة الفروق بين المجموعة التجريبية قبل تطبيق البرنامج وبعد تطبيقه على الدرجة الكلية لقائمة المودزلي للوسواس القهري (ترجمة فرج والبشر، 2002) قبل تطبيق البرنامج وبعد تطبيقه القائم على الإرشاد الجمعي المعرفي السلوكي باستخدام اختبار (ت) لدلالة الفروق بين المتوسطات، والجدول التالي يوضح ذلك: لئك

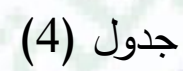

نتائج حساب قيمـة "ت" لمتوسطي درجات المجموعة التجريبية على قائعـة المودزلي للوسواس القهري، قبل تطبيق البرنامج وبعد تطبيقه: 


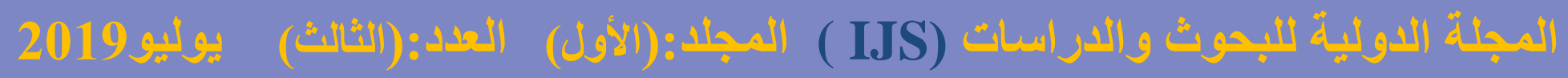
د. رانيا الصاوي عبده عبد القوي، (فاعلية برنامج إرشادي مقترح لخفض الوسواس القهري لدى طالبات الجامعة).

\begin{tabular}{|c|c|c|c|c|c|c|}
\hline & الدلالة & ت & $\varepsilon$ & 5 & ن & المجموعة \\
\hline 0.01 & 0.05 & 34.64 & 0.71 & 24.11 & 10 & التجريبيـــــة قبــــلـ \\
\hline 2.81 & 1.84 & & 0.91 & 4.2 & 10 & التجريبيـــــة بعــــد \\
\hline عنــد مسـتوى & دالـة إ & & & & & 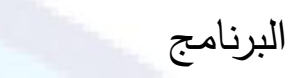 \\
\hline & 0.01 & & & & & \\
\hline
\end{tabular}

يتضـح مـن الجدول (4) أنـهـ توجد فرق دال إحصـائياً عند مستوي دلالمة بلـن ( 0.01 ) بـين متوسطيّ درجات القياسين القبلي والبعدي للمجموعـة التجربيية على قائمسة المودزلي للوسواس القهري، مما يشير إلى تحقق (الفرض الرابع) من فروض الدراسة.

للتأكد من صحة الفرض الخامس والذي ينص على: توجد فروق دالة إحصـائيا بين طالبـات المرحلـة الجامعيـة في الدرجـة الكليـة لمقياس يـل براون للوسواس القهري في القياسين (البعدي والتتبعي) لصالح القياس التتبعي.

للتحقق من هذا الفرض تم دراسة الفروق بين المجموعة التجريبية في القياسين(البعدي والتتبعي) على الدرجة الكلية لمقياس الوسواس القهري يل براون (ترجمة فرج والبشر، 2002) باستخدام اختبار (ت) لدلالة الفروق بين المتوسطات، والجدول التالي يوضح ذلك:

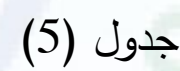

نتائج حساب قيمة "ت" لمتوسطي درجات المجموعة التجربيية على مقياس يل بروان للوسواس القهري في القياسين (البعدي والتتبعي):

\begin{tabular}{|c|c|c|c|c|c|c|}
\hline & الدلالة & ت & $\varepsilon$ & r & ن & المجموعة \\
\hline 0.01 & 0.05 & 0.264 & 0.94 & 4.7 & 10 & 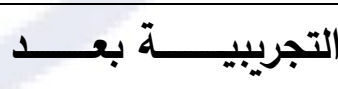 \\
\hline 3.25 & 2.26 & & \multirow[t]{2}{*}{0.96} & \multirow[t]{2}{*}{4.9} & \multirow[t]{2}{*}{10} & \multirow{2}{*}{ 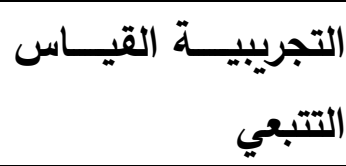 } \\
\hline & غير دالن & & & & & \\
\hline
\end{tabular}




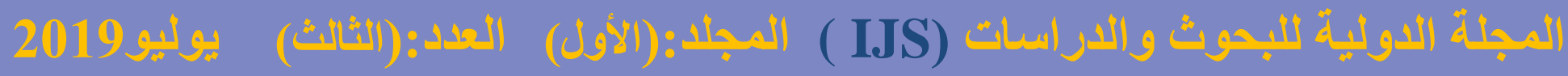

د. رانيا الصاوي عبده عبد القوي، (فاعلية برنامج إرشادي مقترح لذفض الوسواس القهري لاى طالبات الجامعة).

يتضـح من الجدول(5) أنه لا يوجد فرق دال إحصائياً، بين متوسطيّ درجات القياسين البعدي

وما بعد المتابعة للمجموعة التجريبية على مقياس يل براون للوسواس القهري، مما يثير إلى عدم

تحقق "الفرض الخامس" من فروض الدراسة.

للتأكد من صحة الفرض السادس والذي ينص على : توجد فروق دالة إحصائيا بين

طالبـات المرحلـة الجامعيـة في الدرجـة الكليـة لقائمـة المـودزلي للوسواس القهري في القياسين

$$
\text { (البعدي والتتبعي) لصالح القياس التتبعي. }
$$

للتحقق من هذا الفرض تم دراسة الفروق بين المجموعة التجريبية في القياسين (البعدي

والتتبعي) على الدرجة الكلية لقائمـة المودزلي للوسواس القهري (ترجمـة فرج والبشر، 2002)

باستخدام اختبار (ت) لدلالة الفروق بين المتوسطات، والجدول التالي يوضح ذلك:

جدول (6)

نتائج حساب قيمـة "ت" لمتوسطي درجات المجموعـة التجريبية على قائهـة المودزلي للوسواس القهري في القياسين (البعدي والتتبعي):

\begin{tabular}{|c|c|c|c|c|c|c|}
\hline & الدلالة & ت & $\varepsilon$ & ? & ن & المجموعة \\
\hline 0.01 & 0.05 & \multirow{4}{*}{0.282} & 0.91 & 4.2 & 10 & 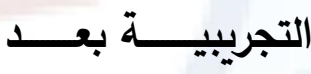 \\
\hline & & & 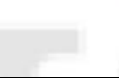 & & & البرنامج \\
\hline 3.26 & 2.28 & & \multirow[t]{2}{*}{0.97} & \multirow[t]{2}{*}{4.6} & \multirow[t]{2}{*}{10} & \multirow[t]{2}{*}{ التجريبيــة القيــاس } \\
\hline[ & 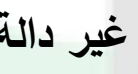 & & & & & \\
\hline
\end{tabular}

يتضـح من الجدول(6) أنه لا يوجد فرق دال إحصائياً، بين متوسطيّ درجات القياسين البعدى لئي وما بعد المتابعة، للمجموعة التجريبية على قائمة المودزلي للوسواس القهري، مما يشير إلى عدم تحقق "الفرض السادس" من فروض الدراسة. 


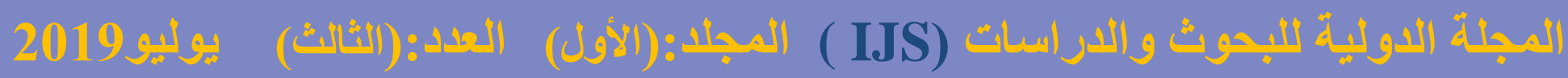
د. رانيا الصاوي عبده عبد القوي، (فاعلية برنامج إرشادي مقترح لذفض الوسواس القهري لاى طالبات الجامعة).

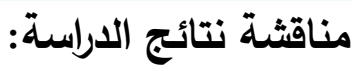

أيدت النتائج التي توصلت إليها الباحثة من خلال التحليل الإحصائي، فاعلية برنامج

العلاج السلوكي المعرفي في تخفيف أعراض الوسواس القهري للى عينـة الدراسة من طالبات

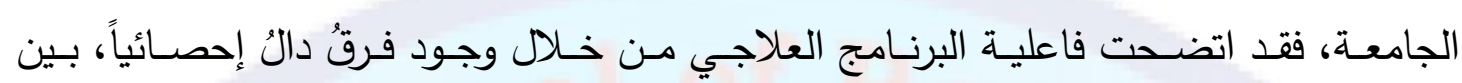
متوسطيّ درجات المجموعتين التجريبية والضابطة على مقياس يل براون للوسواس القهري وقائمة المودزلي للوسواس القهري، بعد تطبيق البرنامج العلاجي، لصـالح المجموعة التجريبية (تحقق بـقي

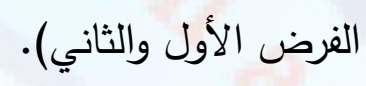

كما اتضحت فاعلية البرنامج العلاجي أيضا من خلال وجود فرق دال إحصائياً بين متوسطيّ درجات القياسين القبلي والبعدي للمجموعة التجريبية على مقياس يل براون للوسواس القهري وقائمة المودزلي للوسواس القهري، لصالح التطبيق البعدى (تحقق الفرض الثالث والرابع).

أكدت النتائج استمرارية فاعليـة البرنـامج في تخفيف أعـراض الوسـواس القهري للدى

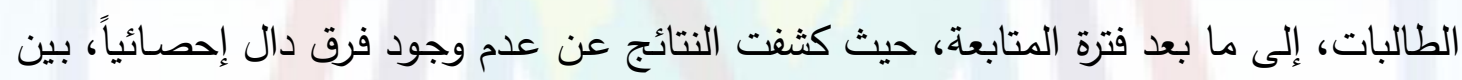
متوسطيّ درجات القياسين البعدي وما بعد المتابعة، للمجموعة التجريبية على مقياس يل براون

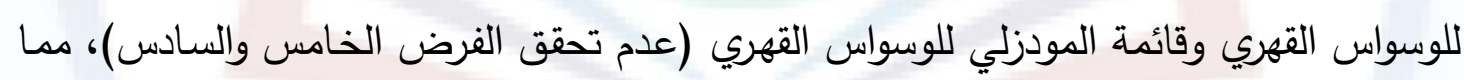
يؤكد على استمرارية فاعلية البرنامج العلاجي إلى ما بعد فترة المتابعة، مما يشير إلى استمرار اثر بقاء التعلم لاى طالبات المرحلة الجامعية.

بنـاءً على مـا سبق، فقد أكدت نتائج الدراسـة الحاليـة على فاعلية برنـامج العـلاج السلوكي المعرفي في تخفيف أعراض الوسواس القهري. وبذلك تتفق نتائج الدراسة الحالية مـع

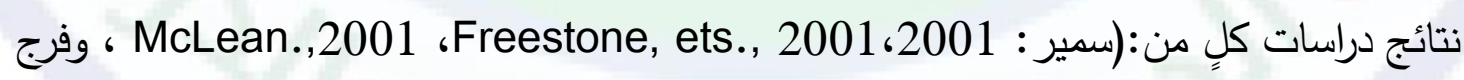

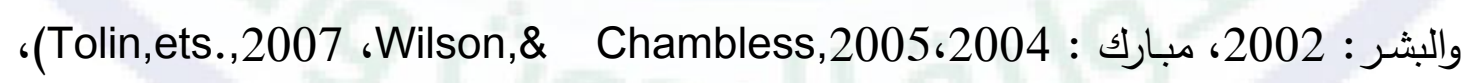
وهى الدراسات التي ركزت على استخدام برامج العلاج المعرفي السلوكي في عـلاج الوسواس القهري.

فقد استخذمت هذه الدراسـات فنيـات العـلاج المعرفي السـلوكي التاليـة: إعـادة البنـاء المعرفي، والتعريض ومنـع الاستجابة، والحـوار، وفنيـة الاسترخاء، كمـا استخدمت فنيـة وقف 
د. رانيا الصاوي عبده عبد القوي، (فاعلية برنامج إرشادي مقترح لخفض الوسواس القهري لاى طالبات الجامعة).

الأفكار، وهى من الفنيات التي استخدمتها الباحثة أثناء تطبيق الجلسات الخاصـة بالبرنامج، مما أعطى ثراءً وفاعلية للبرنامج العلاجي، مما اتضح من خلال تخفيف أعراض الوسواس القهري.

كما طرأ تغيّر بفعل البرنـامج العلاجي، كما تم التعبير عنهـ بشكل إحصـائي، أما عن التغيرات الكيفية التي لاحظتها وسجلتها الباحثة على الطالبات بعد تطبيق البرنامج العلاجي في إطار الدراسة الحالية، حيث تلقت مجموعة من الطالبات بالمرحلة الجامعية(المجموعة التجريبية)، علاجاً نفسياً مكثفاً مدمجاً بالاسترخاء وبمحاولات متكررة ومتعددة للتدريب على فنيات العلاج السلوكي المعرفي من أجل التخفيف من وطأة وألم وكرب وضيقهن بسبب الوسواس القهري، بل ومن أجل التغلب على الوسواس القهري في حد ذاته، حيث كانت الطالبة تثارك في كل أنشطة الجلسة من أولها وحتى نهايتها، تفعيلاً للاتفاق المبرم بين الباحثة والطالبة عن أهمية المشاركة

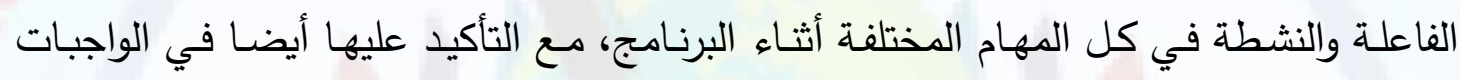
المنزليـة، وذلك باستخدام عدة فنيات تمثلت في: فنيـة التحصين التدريجي وتقليل الحساسية التدريجي، وفنية وقف الأفكار ، وفنية الاسترخاء، وفنية إعادة البناء المعرفي، وفنية لعب الدور.

هذا بالإضافة إلى التعزيز (حتى يتم تدعيم وتشجيع الطالبات الجامعيات على ممارسة

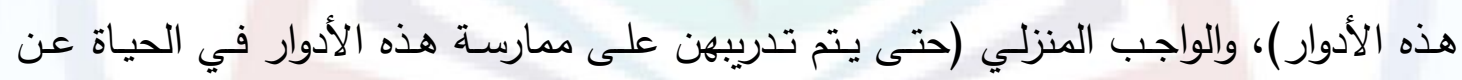
طريق الأسرة في المنزل )، وبخاصة أن الأفكار الوسواسية والأفعال القهرية ذات صفة الإلحاح الفجاءة فهي تقتحم على الطالبة خلوتها ،كما تقتحم عليهن وهن وسط المجال الأكاديمي، وبين الناس وهن في الطريق، بل وفى فراشهن وقضاءهن لحاجتهن فكانت الفنيات نعم المعين للطالبة

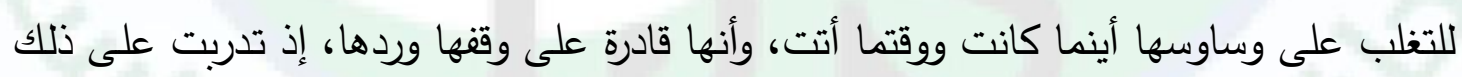
بسبل شتى، فتارة تستخدم وقف الأفكار، وفى كل جلسة يتم تحديد فكرة أو فعل وسواسي قهري لكي يتم التدريب على كيفية التغلب عليها وبكل الفنيات التي يمكن استخدامها داخل الجلسة، وتقوم الطالبة بتكرار ذلك في منزلها وجامعتها وفي كل مكان، وكانت الجلسات تتم فيها كافة الإجراءات في جو من الألفة، مع المناقثات المستمرة بهدوء، وكانت الطالبات تسجلن ذلك في تقاريرهن اللاتي يسجلن فيها ما حدث لهن بعد انتهاء الجلسة، حتى الجلسة التي تليها، حيث كانت الباحثة تراعي مراجعة تلك التقارير في أول كل جلسة، ويستفدن منها في موضوع الجلسة الجديد، حيث تحرص على مراجعتها تحقيقاً لأهداف ومبادئ وأسس وخطوات العلاج السلوكي 


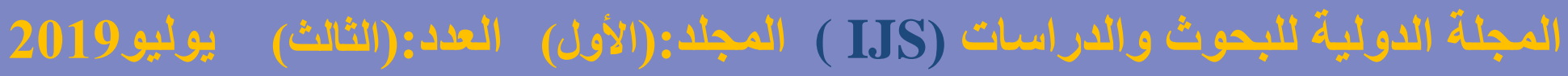

د. رانيا الصاوي عبده عبد القوي، (فاعلية برنامج إرشادي مقترح لخفض الوسواس القهري لاى طالبات الجامعة).

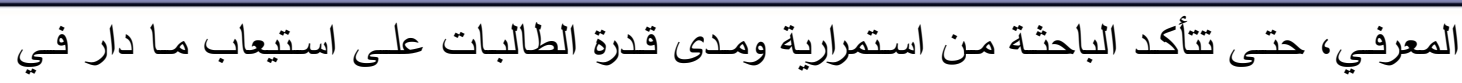
الجلسة، وكيفية تتفيذها لذلك خارج الجلسة.

ترجع الباحثة نجاح برنامج العلاج النفسي السلوكي المعرفي الجمي في خفض أعراض الوسواس القهري لدى عينة الدراسة إلى عدد من الأسباب منها ما يلي:

1- مراعاة البرنامج لخصائص العينة خاصة في المرحلة العمرية من (20: 22) سنة، مرحلة

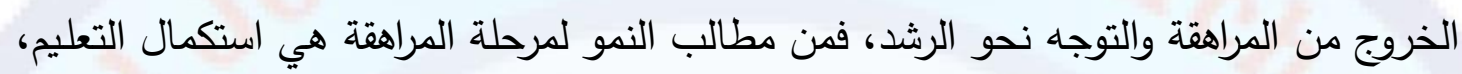
ونمو الثقة بالنفس، والثعور بكيان الفرد، تكوين الكفاهيم والمهارات، ومن مطالب النمو لمرحلة الثرانة

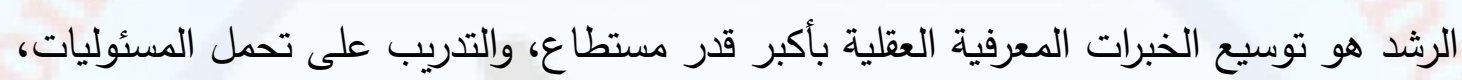
وتحقيق الاتزان الانفعالي كما كان يسعى البرنامج إلى تحقيقه وحرص على ذلك من الكن خلاتل

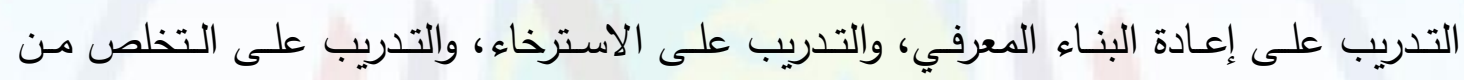

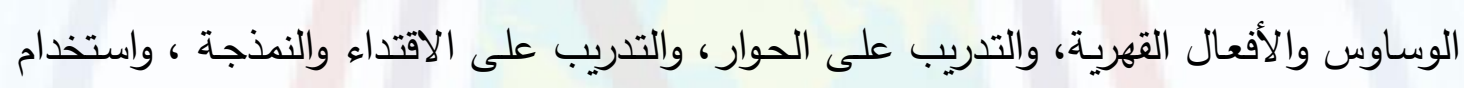

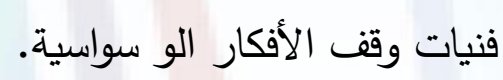

2- مراعاة البرنامج لأسس ومبادئ العلاج النغسي السلوكي المعرفي وبخاصة مرحلة بناء العلاقة

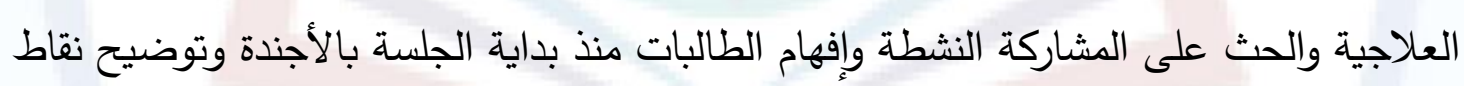

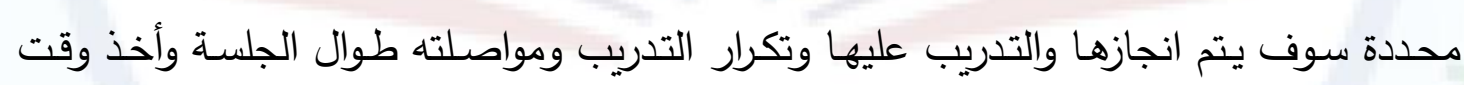
للاسترخاء وتوظيفه في خدمة الجلسة، مح التركيز على الأفكار الوسواسية والأفعال القهرية التهابة

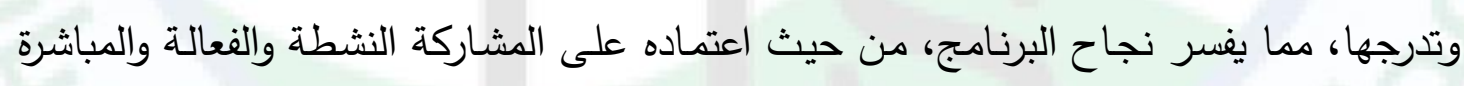

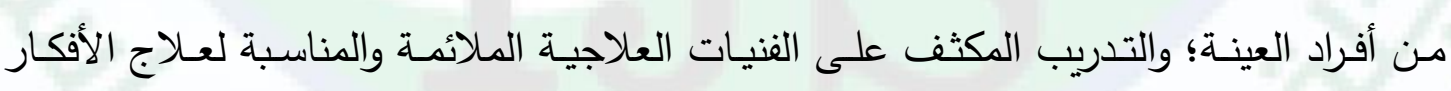
الوسواسية والأفعال القهرية التي يعانى منها أفراد العينة.

3- اعتماد البرنامج على الجدولة والأنشطة والواجبات المنزلية التي تقوم بها الطالبة بالجلسة

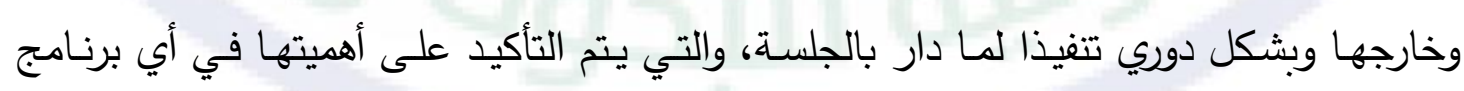
علاجي نفسي سلوكي معرفي.

4- اعتماد البرنامج على نقاط محدة لتتميتها، وهي الأهداف الإجرائية التي ركزت عليها

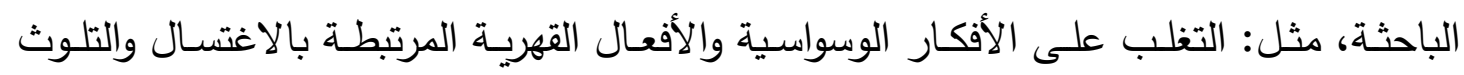




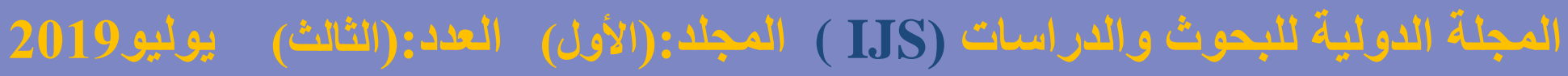
د. رانيا الصاوي عبده عبد القوي، (فاعلية برنامج إرشادي مقترح لخفض الوسواس القهري لاى طالبات الجامعة).

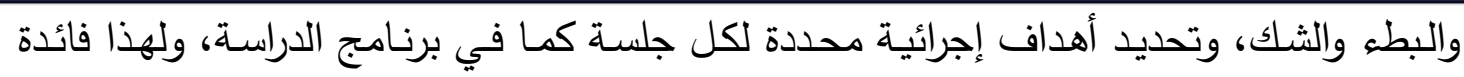
مزدوجة فمن ناحية المساهمة في تحقيقها واختيار الفنيات الملائمة والتدريب عليها.

5- اعتمـاد البرنـامج على شرح كل فنيـة قبل البدءء بها، وتحديد مخطط كل جلسـة ومناقثـة الطالبة، وتقديم ملخص لكل جلسة مرة مكتوبا ومرة بثكل شفهي ومرات بشكل عملي، ولا يتم الانتقال دونما استيعاب وتتفيذ كل نقطة وهدف إجرائي، والبدء بإقناع الطالبات بأهمية ومبادئ وجدوى العلاج.

6- اعتماد البرنـامج على أسلوب التعزيز الإيجابي والتشجيع، فقد جمع البرنـامج بين أسلوبي

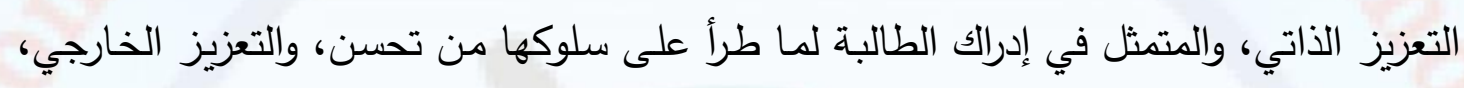
والمتمثل في تثجيع الباحثة للطالبة عند قيامها بالأداء الصحيح للفنية التي تكون الطالبة بصدي إلى تنفيذها.

أما عن استمرارية فاعلية البرنامج العلاجي المستخدم، فقد تأكدت من خلال التحقق من استمرار التحسن في مهارات عينـة الدراسـة في التغلب على الوسـاوس والأفعال القهريـة وأداء الفنيات العلاجية بشكل دوري إلى ما بعد فترة المتابعة، لأن الإرشاد النفسي السلوكي المعرفي

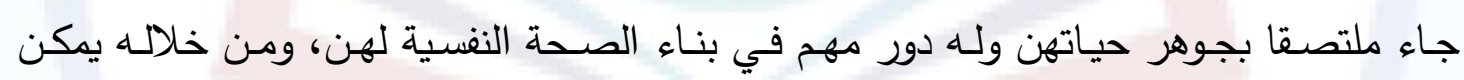
التغلب علي ضغوط الحياة الحديثة، وبالتالي فإن البرنامج المستخدم يكون قد حقق أحد الأهداف دهاء الأساسية لبرامج تعديل الأفكار الوسواسية بشكل عام، فالهدف من إجراء برامج تعديل السلوك ليس إحداث تغيرات طارئة مؤقتة في جوانب الثخصية المختلفة، ثم لا تلبث أن تتطفئ وكأن شيئا لم يكن، بل إن المطلوب في هذه البرامج هو أن يظل أثرها حتى بعد توقف التدريبات التي كانت تتلقاها الطالبات أثناء جلسات تلك البرامج، وحتى بعد انقطاع صلتهم بالقائم على التدريب. فــن الأمسور الأساسية في إجـراء البرامج التأكد مـن استمرار فاعليتها مـع طالبات المجموعة التجريبية، بعد توقف جلسات تطبيق البرنامج، الأمر الذي يدفع نحو الثقة في أن الن الناه

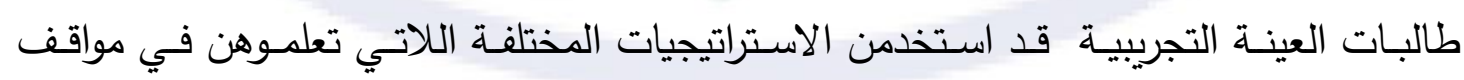
حياتهن، دون اللجوء إلى المعالجة النفسية، وأيضا الأمر الذي يعطي مبرراً لمحاولة تطبيق تلك تلكئك

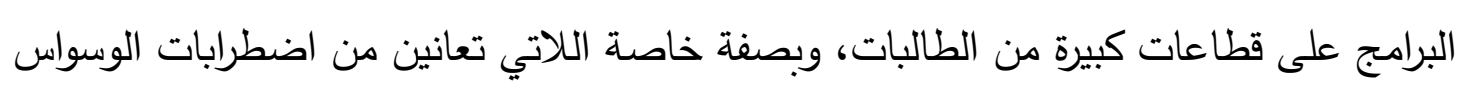




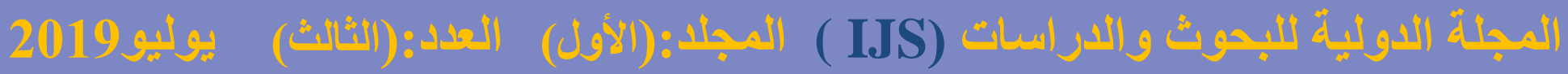
د. رانيا الصاوي عبده عبد القوي، (فاعلية برنامج إرشادي مقترح لخفض الوسواس القهري لاى طالبات الجامعة).

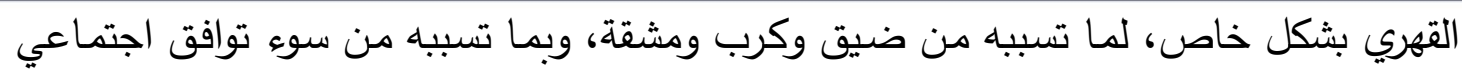
ومشكلات نفسية وأكاديمية.

توصيات: 1- أهميـة إنشـاء نـوادي جامعيـة لمســاندة الطالبـات ذوات اضـطراب العصـاب القهري، وفتتح العيادات والمراكز الإرشادية لتقديم الخدمات الإرشادية والعلاجية المجانية لهن، فهن في أمس الحاجة إلى تلك الرعاية، ولا يجب تركهن فريسة لهذا الاضطراب لما فيه من هدر وفقد للطاقة الإيجابية التي يمثلنها. 2- ضرورة عقد الدورات التدريبية والندوات التثقيفية المستمرة لأسر ذوات اضطراب الوسواس القهري ومعلميهم، ومرافقيهم للتغلب على هذا الاضطراب من خلال التوعية والتثقيف. 3- أهمية الاهتمام بالتدخل المبكر من خلال الحد من اضطراب الوسواس القهري عبر التوعية بدور التتشئة والبيئة التي ينمو فيها هذا الاضطراب وكيفية الوقاية منه. 4- تدريب الأخصائيين والأطباء النفسيين على ممارسة العلاج النفسي المعرفي السلوكي لما فيه من فوائد علاجية يعود نفعها على الموارد البشرية في المجتمع. 5- عقد الدورات التدريبية والندوات التثقيفية لأساتذة الجامعات للتوعية بكيفية التعامل مع ذوات اضطراب العصاب القهري. 6- أهمية التدريب على الإرشاد والعلاج النفسي المعرفي السلوكي وفنياته المتعددة في مناهج كليات التربية وبخاصة مع المتعاملين في الميدان الإكلينيكي، وتضمين ذلك مناهج علم النفس لإنس ونس العلاجي.

7- مساعدة الطالبات على التغلب على اضطراباتهن ومشكلاتهن وفهم الدوافع وراء تصرفاتهن، والعمل على تحقيق توافقهن الاجتماعي.

8- الاهتمام بالرعاية المتكاملة للطالبات، في جميع النواحي الصحية والنفسية، والاجتماعية. 9- الاهتمام بالأنشطة الجامعية والاجتماعية المحببة للطالبات، وتوظيفها في تحسين قدراتهن. 


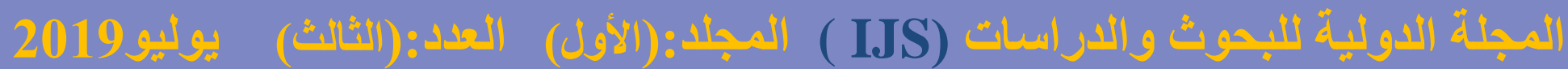
د. رانيا الصاوي عبده عبد القوي، (فاعلية برنامج إرشادي مقترح لخفض الوسواس القهري لاى طالبات الجامعة).

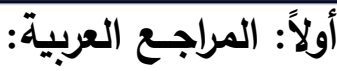

1- الثطرات، وليد .(2001).فاعلية برنامج إرشاد جمعي معرفي سلوكي في معالجة الأرق وخفض التوتر ، رسالة ماجستير غير منشورة ، الجامعة الأردنية ، عمان ، الأردن.

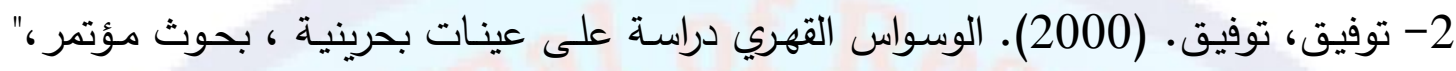
الخدمة النفسية والتنمية "، قسم علم النفس ، كلية العوم الاجتماعية ، جامعة الكويت ، الكويت.

3- سمير، ايرينى.(2001). فعالية العلاج العقلاني الانفعالي السلوكي في خفض مستوى الوساوس القهرية لاى عينة من طلاب الجامعة , رسالة ماجستير، كلية التربية جامعة الزقازيق. 4- عبد الظاهر، عبد الله. (2008). فاعلية برنامج قائم على استراتيجيات ما وراء المعرفة في

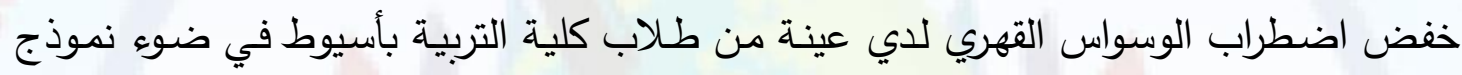
ويلز وماتثيوس, رسالة دكتوراه، كلية التربية، جامعة أسيوط. 5- عكاشة، أحدد. (2003). الطب النفسي الدعاصر، القاهرة ، الأنجلو الصصرية. 6- فرج، صفوت؛ والبشر،سعاد. ( 2002). الدقارنة بين كل من العلاج السلوكي بأسلوب التعرض ومنع الاستجابة وبين العلاج الدوائي لمرضى الوسواس القهري, مجلة دراسات نفسية،

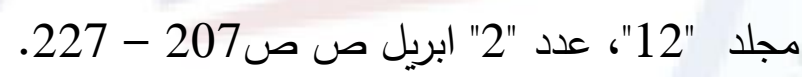

7- فرج، صفوت؛ والبثر ،سعاد. ( 2002).مقياس يل براون للوسواس ( مترجم )، مكتبة الانجلو

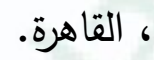

8- فرج، صفوت؛ والبشر ،سعاد. ( 2002).قائمة المودزلي للوسواس القهري ( مترجم )، مكتبة

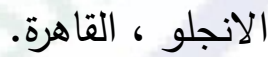

9- لنيدزاى، وبول. (2000). مرجع في علم النفس الإكلينيكي للاراشين , ترجمة: صفوت فرج،

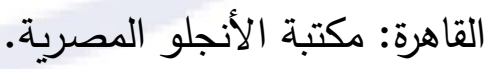




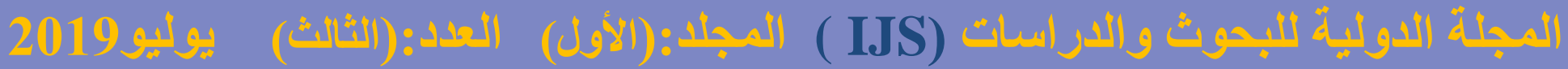
د. رانيا الصاوي عبده عبد القوي، (فاعلية برنامج إرشادي مقترح لخفض الوسواس القهري لاى طالبات الجامعة).

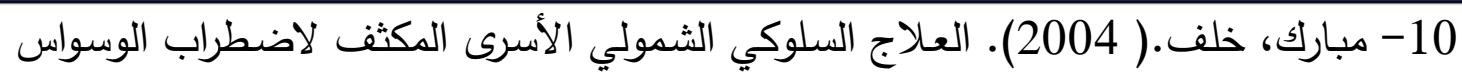

القهري المصـوب باضطرابات انفعالية أخرى في الطفولـة المتأخرة "دراسـة حالة", مجلة كليـة

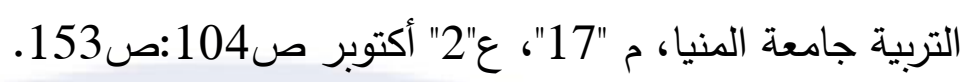

11- مقدادي ، يوسف.( 2008 ). فاعلية برنـامج إرشاد جمعي معرفي سلوكي في خفض

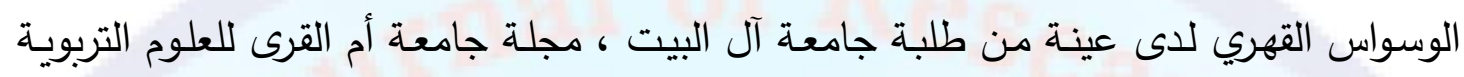
والنفسية ، المجلد العشرون - العدد الثاني - يوليو.

12- هولاند ـ( 2006). اضطراب الوسواس القهري، في: ليهي، روبرت: دليل عملي تفصيلي لممارسة العلاج النفسي المعرفي في الاضطرابات النفسية، ترجمة :جمعة يوسف وحمح الصبوة. القاهرة : ايتراك للطباعة والنشر والتوزيع.

13. Anderson, R., \&Rees, C.(2007). Group versus individual cognitivebehavioral treatment for obsessive-compulsive disorder. A controlled trial. Behavior Research and therapy, 45,P.p 123:137.

14. Brad burg, C. (2005). Examination of the Relationship between Obsession Beliefs and Cognitive Flexibility in Obsessive Compulsive Disorder. DAI-B 66/06, P.3398, Dec. AAT 317

15. Freestone, H., Loger, E.,\& Ladouceur, R .(2001).Cognitive Therapy of Obsessive Thoughts. Cognitive and Behavioral Practice 8, P.p 61:78 .

16. Green, A. (2005). Symptom Reduction in Intensive CognitiveBehavioral Treatment of Obsessive-Compulsive Disorder: The Role of Change in Beliefs about the Appraisals of Intrusive Thoughts. DAI-B 66/06, P.3409. Rosalind Franklin University of Medicine and Science, $\mathrm{PhD}$.

17. Guggisberg, K. (2005). Methodological Review and Meta-Analysis of Treatments for Child and Adolescent Obsessive- Compulsive Disorder. DAI-B 66/02, P.1170, Aug, The University of Utah, Ph.D.

18. Himle, A.(2006). Videoconferencing-based cognitive-behavioral therapy for obsessive- compulsive disorder. Behavior Research and Therapy, 44,P.p 1821:1829 
د. رانيا الصاوي عبده عبد القوي، (فاعلية برنامج إرشادي مقترح لخفض الوسواس القهري لاى طالبات الجامعة).

19. Keller, M. (2000). A Comparison of Nefazodone, the Psychotherapy, and Their Combination for the Treatment of Chronic Depression. New England Journal of Medicine, 342, 1422:1470

20. McLean. P.(2001).Cognitive versus behavior therapy in the group treatment of obsessive Compulsive disorder. Journal of consult psychology. 14, April, P.p69: 205.

21. Nasayuki, O., Masahiro, K., \& Yoshio, M. (2003). Features of Obsessive-Compulsive Disorder in Patients Primarily Diagnosed with Schizophrenia. Psychiatry and Clinical Neurosciences, 57(1), 67:74.

22. Rufer, M., Fricke, S., Moritz, S., Kloss, M., \& Hand, I. (2006).Find More Like This Symptom Dimensions in Obsessive-Comprediction of Cognitive-Behavior Therapy Outcome. Acta Psychiatric Scandinavia, 113(5), 440:444.

23. Rufer, M., Fricke, S., Moritz, S., Kloss, M., \& Hand, I. (2006).Find More Like This Symptom Dimensions in Obsessive- Comprediction of Cognitive-Behavior Therapy Outcome. Acta Psychiatric Scandinavia, 113(5), 440:444.

24. Sookman, D., \& Steketee, G.(2007). Directions in Specialized Cognitive Behavior Therapy for Resistant Obsessive-Compulsive Disorder: Theory and Practice of Two Approaches". Cognitive and Behavioral Practice 14, P.p 1:17 .

25. Tolin, D. F., Hannan, Maltby, Diefenbach, Worhunsky, \& Brady.(2007) .A Randomized Controlled Trial of Self-Directed Versus Therapist-Directed Cognitive-Behavioral Therapy for ObsessiveCompulsive Disorder Patients. Behavior Therapy, 25, P.p 26 :78.

26.Wilhelm, S, \& Steketee, G.,(2005). Effectiveness of Cognitive Therapy for Obsessive- Compulsive Disorder: An Open Trial. Journal of Cognitive Psychotherapy: An International Quarterly, Vol 19, No 2, P.p 173-179 .

27.Wilson, K., \&Chambless, D,(2005).Cognitive therapy for obsessivecompulsive disorder. Behavior Research and Therapy, 43, P.p 1645-1654 


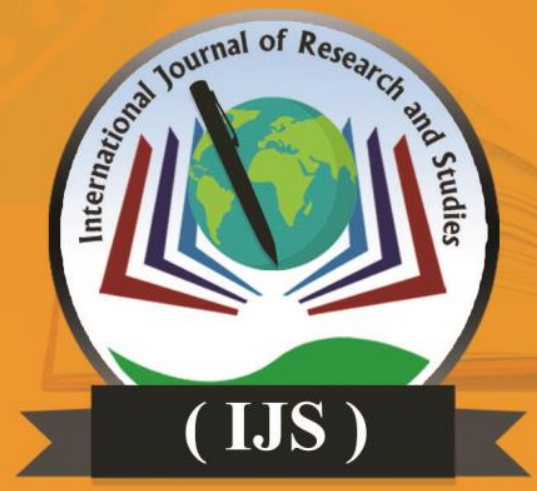

International Journal of Research and Studies

$$
\text { ( IJS ) }
$$

